\title{
Educational Equipment Planning in Portugal Over the Last Decades
}

Article · October 2016

CITATIONS

0

3 authors:

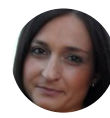

\section{Lúcia Santos}

University of Coimbra

25 PUBLICATIONS 11 CITATIONS

SEE PROFILE

\section{Luís Alcoforado}

University of Coimbra

35 PUBLICATIONS 11 CITATIONS

SEE PROFILE
READS

92
António Manuel Rochette Cordeiro

University of Coimbra

81 PUBLICATIONS 61 CITATIONS

SEE PROFILE

Some of the authors of this publication are also working on these related projects:

Territorialização da Educação View project

REORGANIZAÇÃO DA REDE DO ENSINO PARTICULAR E COOPERATIVO COM “CONTRATO DE ASSOCIAÇÃO View project 
ISSN 2161-6248

DOI: $10.17265 / 2161-6248$

From Knowledge to Wisdom

\section{US-Chine \\ Eduoation Review}

Volume 6, Number 10, October 2016
Educat i on Theory




\section{US-China Education Review B}

Volume 6, Number 10, October 2016 (Serial Number 65)

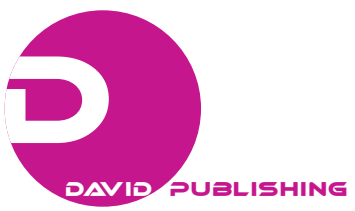

David Publishing Company

www.davidpublisher.com 
Publication Information:

US-China Education Review B (Earlier title: Journal of US-China Education Review, ISSN 1548-6613) is published monthly in hard copy (ISSN 2161-6248) by David Publishing Company located at 616 Corporate Way, Suite 2-4876, Valley Cottage, NY 10989, USA

\begin{abstract}
Aims and Scope:
US-China Education Review B, a monthly professional academic journal, covers all sorts of education-theory researches on Higher Education, Higher Educational Management, Educational Psychology, Teacher Education, Curriculum and Teaching, Educational Technology, Educational Economics and Management, Educational Theory and Principle, Educational Policy and Administration, Sociology of Education, Educational Methodology, Comparative Education, Vocational and Technical Education, Special Education, Educational Philosophy, Elementary Education, Science Education, Lifelong Learning, Adult Education, Distance Education, Preschool Education, Primary Education, Secondary Education, Art Education, Rural Education, Environmental Education, Health Education, History of Education, Education and Culture, Education Law, Educational Evaluation and Assessment, Physical Education, Educational Consulting, Educational Training, Moral Education, Family Education, as well as other issues.
\end{abstract}

\section{Editorial Board Members:}

Asst. Prof. Dr. Güner Tural

Prof. Alexandro Escudero

Prof. Diane Schwartz

Prof. Gordana Jovanovic Dolecek

Prof. Käthe Schneider

Prof. Michael Eskay

Prof. Smirnov Eugeny
Associate Prof. Rosalinda Hernandez

Prof. Cameron Scott White

Prof. Ghazi M. Ghaith

Prof. Grigorios Karafillis

Prof. Lihshing Leigh Wang

Prof. Okechukwu Sunday Abonyi

Prof. Yea-Ling Tsao
Prof. Aaron W. Hughey

Prof. Deonarain Brijlall

Prof. Gil-Garcia, Ana

Prof. James L. Morrison

Prof. Mercedes Ruiz Lozano

Prof. Peter Hills

Manuscripts and correspondence are invited for publication. You can submit your papers via Web submission, or E-mail to teacher@davidpublishing.com or teacher@davidpublishing.org. Submission guidelines and Web submission system are available at http://www.davidpublisher.com.

\title{
Editorial Office:
}

616 Corporate Way, Suite 2-4876, Valley Cottage, NY 10989, USA

Tel: $1-323-984-7526,323-410-1082$

Fax: 1-323-984-7374, 323-908-0457

E-mail: teacher@davidpublishing.com; teacher@davidpublishing.org; education1548@hotmail.com; or edu1658@yahoo.com.

Copyright $(2016$ by David Publishing Company and individual contributors. All rights reserved. David Publishing Company holds the exclusive copyright of all the contents of this journal. In accordance with the international convention, no part of this journal may be reproduced or transmitted by any media or publishing organs (including various Websites) without the written permission of the copyright holder. Otherwise, any conduct would be considered as the violation of the copyright. The contents of this journal are available for any citation. However, all the citations should be clearly indicated with the title of this journal, serial number and the name of the author.

\section{Abstracted/Indexed in:}

Database of EBSCO, Massachusetts, USA

Chinese Database of CEPS, American Federal Computer Library center (OCLC), USA

Chinese Scientific Journals Database, VIP Corporation, Chongqing, P.R.C.

NSD (Norwegian Social Science Data Service), Database for Statistics on Higher Education (DBH), Norway Universe Digital Library Sdn Bhd (UDLSB), Malaysia

\section{Subscription Information:}

Price (per year): Print $\$ 600$

David Publishing Company

616 Corporate Way, Suite 2-4876, Valley Cottage, NY 10989, USA

Tel: 1-323-984-7526, 323-410-1082

Fax: 1-323-984-7374, 323-908-0457

E-mail: order@davidpublishing.org
Excellent papers in ERIC

Summon Serials Solutions

Polish Scholarly Bibliography (PBN)

Turkish Education Index

Google Scholar

CNKI

J-GATE

Scribd Digital Library

Airiti

Academic Key

Electronic Journals Library (EZB)

CiteFactor, USA
SJournal Index

Scientific Indexing Services

New Jour

Pubicon Science

Sherpa Romeo

Scholarsteer

WorldCat

Infobase Index

Free Libs

Pubget

CrossRef

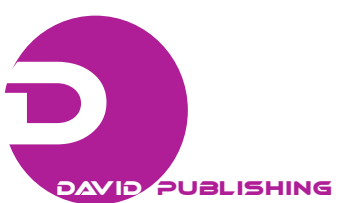

David Publishing Company www.davidpublisher.com 


\section{US-China}

Education Review $B$

Volume 6, Number 10, October 2016 (Serial Number 65)

\section{Contents}

\section{History Education}

Educational Equipment Planning in Portugal Over the Last Decades

Lúcia Santos, A. M. Rochette Cordeiro, Luís Alcoforado

Women Who Have Run for U.S. President-A Historical Look at Leadership

From the 1870's to the Present

Paul E. Kotz

\section{Physical Education}

Effects of Different-Term Acute Swimming Exercises on Oxidative Stress Parameters in Rat Cerebellum Tissue

Öznur AKYÜZ

Possible Explanation for Cancer in Rats due to Cell Phone Radiofrequency Radiation

Bernard J. Feldman

\section{Sociology of Education}

Between Sociological Theory and Professional Practice: Integration Experiences in University Traineeship Programmes

Marco Accorinti

\section{Educational Psychology}

The Views of University Students on Guilt in Turkey 



\title{
Educational Equipment Planning in Portugal Over the Last Decades ${ }^{*}$
}

\author{
Lúcia Santos, A. M. Rochette Cordeiro, Luís Alcoforado \\ University of Coimbra, Coimbra, Portugal
}

\begin{abstract}
In the last 80 years, Portugal has suffered profound political, demographic, social, and economic changes, from a dictatorial regime to a democratic system, from a young population society to an ageing population society, and from a rural economy to a service economy. In terms of education, it has progressed from an education for the elites, with a compulsory education period of about three years, to an education for everyone and for a longer period, in which the compulsory education extended to 12 years. The educational resources planning has not always been well adjusted to the conceptual and legislative framework and the demographic and socioeconomic needs, but the recent community funding (2007-2013) has created the conditions to give a fresh impetus to the planning of infrastructures as well as rethink their assumptions, and Portugal now has schools that are more well adapted to the characteristics of modern Portuguese society. This research project seeks to understand the current state of education in Portugal through the analysis of its main tendencies in recent decades, illustrating the relation between the purpose of education, political decisions and social dynamics, and the educational resources planning through the evolution of the school network over this period. This research paper is based upon a thorough diachronic documentary research, focusing on case studies of high and low density territories in central Portugal, which leads to the gathering of evidence that, despite the national guidelines, the country has not progressed at a uniform rate and that there is a strong interference of the different territorial dynamics in the choices made and the results achieved.
\end{abstract}

Keywords: educational resources, planning, school results

\section{Introduction}

It was during the dictatorial regime of the Estado Novo (1933-1974) that the majority of the current Portuguese public school network was built and since that period, Portugal went through a profound transformation of political, demographic, social, and economic reality. The buildings and the educational equipment reflected the course changes made during this transition process, but not always managed to keep up with the accelerating pace at which the changes occurred, due to the lack of financial resources, and it was only in the first decade of the 21 st century that Portugal gathered the necessary conditions to redesign them for the first time.

At a stage where the investment in buildings and educational equipment has ended, the purpose of this

\footnotetext{
*Acknowledgement: Thanks for the academic funds from Foundation for Science and Technology (No. SFRH/BD/91094/2012).

Lúcia Santos, Ph.D., student, Foundation for Science and Technology, Faculty of Psychology and Education Sciences, University of Coimbra.

A. M. Rochette Cordeiro, Ph.D., professor, Faculty of Arts and Humanities, University of Coimbra.

Luís Alcoforado, Ph.D., professor, Faculty of Psychology and Education Sciences, University of Coimbra.
} 
research project is to analyze the impact of the observed changes in our country (Portugal) in the past 80 years in the educational resources planning and realize how it reflected in the school network characteristics, laying the foundation to envision the future of educational resources planning in Portugal.

The research work focused on the study of public school network of the first cycle of elementary education (for students from six to nine years) and it was based on documentary analysis and case studies, using three territories of central Portugal, two low density territories (Lousã and Mortágua) and a high density territory (Figueira da Foz). These examples have made it possible to make comparisons between the territorial realities, the options followed, and the results achieved in terms of the school success of the students and confirm the existence of very different educational realities.

\section{The Social Transformations Over the Past Eight Decades}

In the early 1930s, after the first republican period, a dictatorial regime called Estado Novo settled in Portugal, which lasted more than four decades (1933-1974). After this long period Portugal re-established a democratic system, which after a troubled transition process was consolidated and stabilized, continuing until our current time. The Carnation Revolution (April 25th, 1974) was the moment that led to the restoration of democracy in Portugal and the following years marked the beginning of a profound transformation in the Portuguese society.

At the beginning of the Estado Novo, Portugal was a young country, with a large number of children, featured a distinctly rural character, and characterized by a highly inefficient accessibilities network. Currently, Portugal is heading towards an antagonistic situation, with an aging population, a number of births that does not guarantee the renewal of generations, an economy based on services, and a network accessibility that developed and spread itself throughout the territory. During this period, there was also a change in the social paradigms, with the integration of women in the labor market and the growth of the middle class, and a littoralisation of the Portuguese population, which was associated with the strong migration exodus from the 1960s and 1970s, transformed large sectors of the interior of Portugal into aged and depopulated territories (Cordeiro, Santos, \& Caridade, 2013; Cordeiro, 2014).

This development of the Portuguese society exerted massive pressure on the educational system and school network, leading to processes of changing and searching for new and innovative educational offers to meet the demands resulting from the pace of the social development process in progress.

\section{Key Moments in the Educational Resources Planning Over the Past Eight Decades}

Over the past 80 years, Portugal has evolved from an elitist education in which compulsory education was of three years, to an education for all and for a longer period in which the compulsory education increased to 12 years. Portugal went through a period, in the 1930s, in which the number of children in the first cycle of the elementary education was high, but only 4,117 students reached higher education $(0.06 \%$ of the Portuguese population), exclusive of the city of Coimbra, to a stage where the school population in the first cycle of elementary education suffered a strong decrease (resulting from the decrease in the number of births) and the number of students attending to higher education has risen to 362,200 individuals in 2014 (3.49\% of the portuguese population), causing the proliferation of the education establishments throughout the country ${ }^{1}$ (Barreto, 2000; Instituto Nacional de Estatística, 1963). Reflecting this development, the illiteracy rate suffered

${ }^{1}$ Retrieved August 15, 2016, from http://www.pordata.pt and http://www.ine.pt. 
a remarkable progress, from $67.8 \%$ in 1930 to $5.2 \%$ in $2011^{2}$.

This radical transformation is the result of a deep evolution observed in terms of educational policy, and more particularly, in the educational resources planning, which their long-term course can be summarized into four key moments, each having very specific characteristics.

The first moment of planning in the Portuguese educational context occurred during the dictatorial regime when the Estado Novo set the objective to extent the benefits of education to all children by increasing the number of schools. This intention is materialized in the presentation of the plan of centenarians in 1940, which undertook the commitment to plan the public school network of the first cycle of elementary education in accordance with the demographic and geographic characteristics of the country, setting the number of buildings to be constructed, their typology and location, and the limit of students per room (Alcoforado, Cordeiro, \& Ferreira, 2012). Even though it was not totally completed, the 20 years following its launch were crucial in the expansion of the public school network of the first cycle of elementary education, contributing to its stabilization and subsequent evolution, producing results that, in general, remained until our days (Alcoforado, Cordeiro, \& Ferreira, 2012).

With the end of the Estado Novo and the advent of the democracy, which marked the beginning of a new and striking stage of the country's history, with the consecration of the right to education in the Constitution of the Portuguese Republic of 1976, and with the publication of the Education System Basic Law in 1986, Portugal entered into a decisive phase for the educational resources planning, with the recognition of its importance and with the presentation of the educational charter as the methodology to follow. This momentum comes from the need to adapt the public school network of the first cycle of elementary education to the changes that have taken place in the society and to the requirements of educational reform, but also from the accession to the European Economic Community, which created again conditions for a concerted policy and a global provisions policy of educational resources (Alcoforado, Cordeiro, \& Ferreira, 2012). This is the first transformation attempt of the public school network of the first cycle of elementary education after the plan of centenarians and of the transfer of competence to the local power in the area of education.

However, this measure did not have the expected result and a few years later the law No. 159/99 of September 14th was published, which, by establishing the principles of administrative decentralization and local power autonomy, gave the municipalities the responsibility to prepare the education charter.

Although it represented a new effort, once again it did not pass the field of intention and the truth is that Portugal entered the 21 st century with schools increasingly unable to meet the growing educational challenges. The necessary changes only occurred with the publication of the law No. 7/2003 of January 15th, which imposed to municipalities the preparation of the education charter, by regulating its process of preparation and approval and its effects. As a municipal instrument of prospective planning of buildings and educational equipment, the education charter created conditions for the municipalities to claim as authors and participants in the reorganization of its public school network of the first cycle of elementary education (Cordeiro, Martins, \& Ferreira, 2014). Given the substantial investment that it required, it only materialized when the tutelage announced funding through the National Strategic Reference Framework 2007-2013. That is why, after two failed attempts, for the first time after the plan of centenarians, Portugal once again rationally redesign the public school network of the first cycle of elementary education.

${ }^{2}$ Retrieved August 15, 2016, from http://www.pordata.pt. 
The current Portuguese public school network of the first cycle of elementary education thus reflects the marks of the options that had been taken in contexts of permanent political, demographic, social, and economic evolution. If the location criteria have changed significantly, the characteristics of the building would suffer a complete transformation. Portugal went from schools of small dimension, scattered through the territory, closed on themselves, with a single level of education and classrooms shared simultaneously by more than one year grade (mostly one or two classrooms), working under the regime of a single teacher and without additional spaces (libraries, sports equipment, school canteens, and multipurpose equipments), to schools of higher dimension, centralized, open to the community, with different levels of education, with a classroom and a teacher for each grade level (four classrooms minimum) and equipped with additional support spaces.

\section{A Comparative Study Between Municipal Options and Discussion of Results}

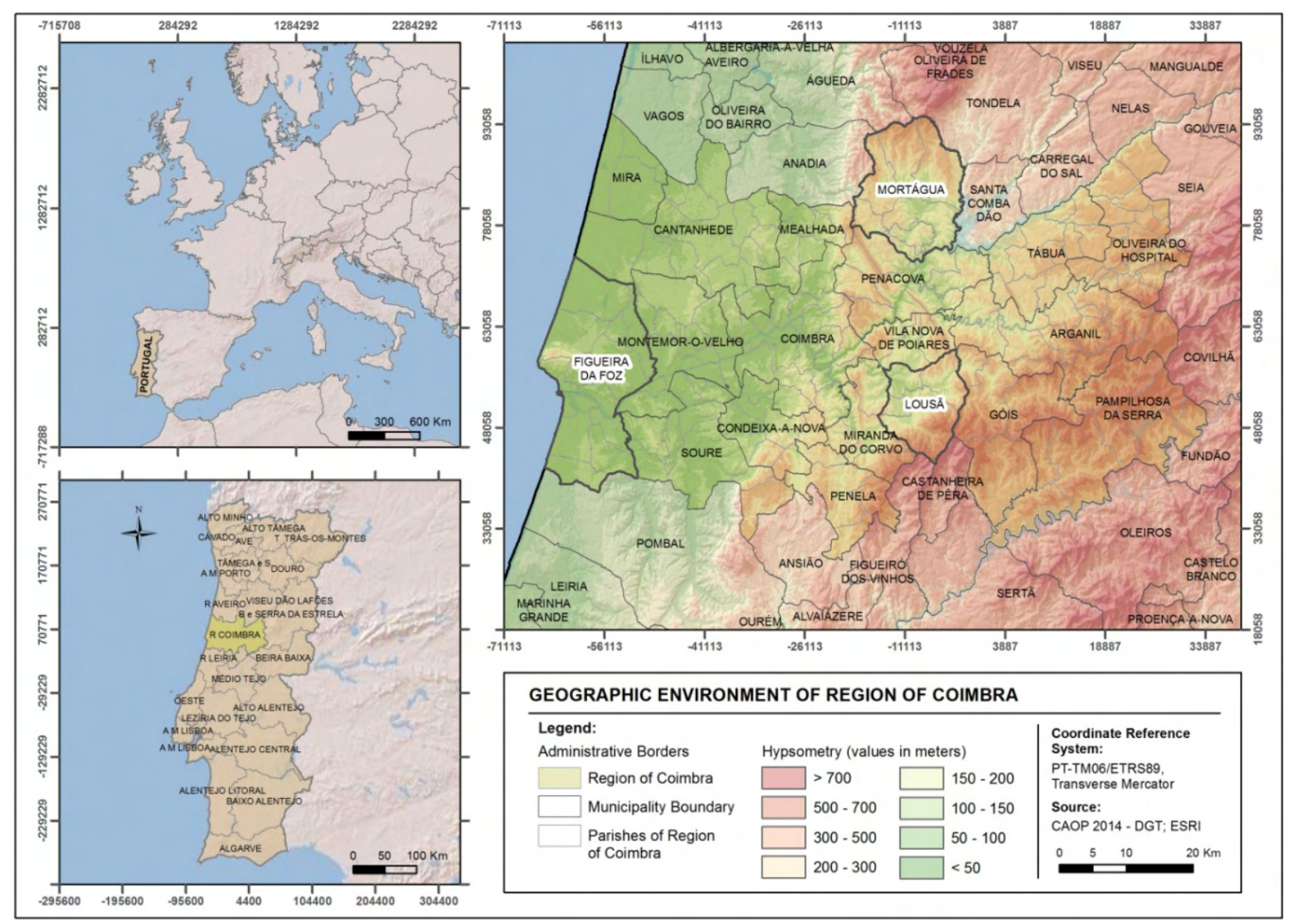

Figure 1. Territorial backgrounds of the municipalities of Lousã, Mortágua, and Figueira da Foz in the central region of Portugal.

To better understand the educational resources planning progress in the past 80 years in Portugal, it seems interesting to analyze the specific cases of three municipalities in central Portugal: Lousã, Mortágua, and Figueira da Foz (see Figure 1). The first two are territories with very identical characteristics. Both located in the central interior, in rural and mountainous areas. They distinguished themselves only by the territorial dimension and the demographic dynamic. Lousã, with smaller dimensions, presented 17,604 inhabitants in 2011 and recorded a very significant population growth in the last decade $(1,851$ residents, value corresponding to $11.75 \%$ ), due to the proximity to the city of Coimbra, the main urban center of the central region (the low 
price of housing transformed this municipality into a "dormitory" of Coimbra). Therefore, in the same period, Mortágua, despite of its higher dimension territory, presented almost half of the resident population $(9,607$ inhabitants) and showed a population decrease (-772 individuals, which presented $-7.44 \%$ ). In contrast, Figueira da Foz is located in the central coast and presented 62,125 inhabitants in 2011. But its prime location did not stop the region from showing a population decline over the past decade ( -476 inhabitants, corresponding to $-0.76 \%$ ), which had its origin in the observed pronounced contrast between the urban center of high density, which has developed in the same pace of the coastal regions, and the rural areas of low density, losing population and presenting high rates of aging.

The municipalities of Lousã, Mortágua, and Figueira da Foz, whose public school network of the first cycle of elementary education were completed during the plan of centenaries, reached the end of the 20th century with a set of mostly obsolete buildings. Given this situation, in the beginning of the 21 st century, right after the publication of the decree-law No. 7/2003 of January 15th and the announcement of community financing, the municipalities promoted the preparation of their education charter (Lousã in 2005, Figueira da Foz in 2006, and Mortágua in 2007), in order to solve the problems of mismatch, maintenance, and governance of the public school network of the first cycle of elementary education, which were intensifying since the 1970s (Matthews, Klaver, Lannert, Ó Conluain, \& Ventura, 2009; Rodrigues, 2010; Cordeiro \& Martins, 2013; Cordeiro, Martins, \& Ferreira, 2014). However, although the guidelines to follow in the preparation of the education charter have been defined at a national level by the Ministry of Education, and, in addition to the specific legislation, several guidance documents have been published, identical assumptions have not always taken into account in the proposals submitted.

In the municipality of Mortágua, the school network reorganization proposal submitted by the education charter reflects the advocated by the Ministry of Education, with the closure of all schools (13 schools) and the construction of a school center (see Figure 2). Located in the central sector of the territory, to facilitate its access and reduce the traveling time of children, this school center was planned according to the full-time school policy (Rodrigues, 2010), providing conditions so that the children could remain throughout the day, such as canteen, library, sports space, and multipurpose areas. With this option, the municipality ensured all students of the municipal territory equal access to buildings and educational equipment of equal or superior quality to that found in large urban centers. It can be considered that the reorganization of the school network belongs to the type "decreed," which occurs when the claims of local actors have full correspondence with the criteria and centrally defined goals (Cordeiro \& Martins, 2013; Cordeiro, Martins, \& Ferreira, 2014).

In the municipality of Lousã, the school network reorganization proposal submitted by the education charter opted, almost entirely, for the maintenance of the existent school network (12 schools), only proposing the closure of two schools, due to the reduced number of students, and the construction of one school, whose main goal was to respond to the needs identified in the municipal territory at the level of second (for students from 10 to 11 years) and third (for students from 12 to 14 years) cycle of elementary education (see Figure 3). According to the municipality, this proposal was based on rational criteria related to the management of public funds, but also on an option to respect the importance of individual history and the symbolism of each building for the local population (Câmara Municipal da Lousã, 2005). The realization of small rehabilitation works, planned in unique operations or in staged intervention programs, was, however, provided, so that the schools could offer, in the medium term, the quality physical conditions in accordance with the rules of educational buildings defined by the Ministry of Education (Câmara Municipal da Lousã, 2005). 


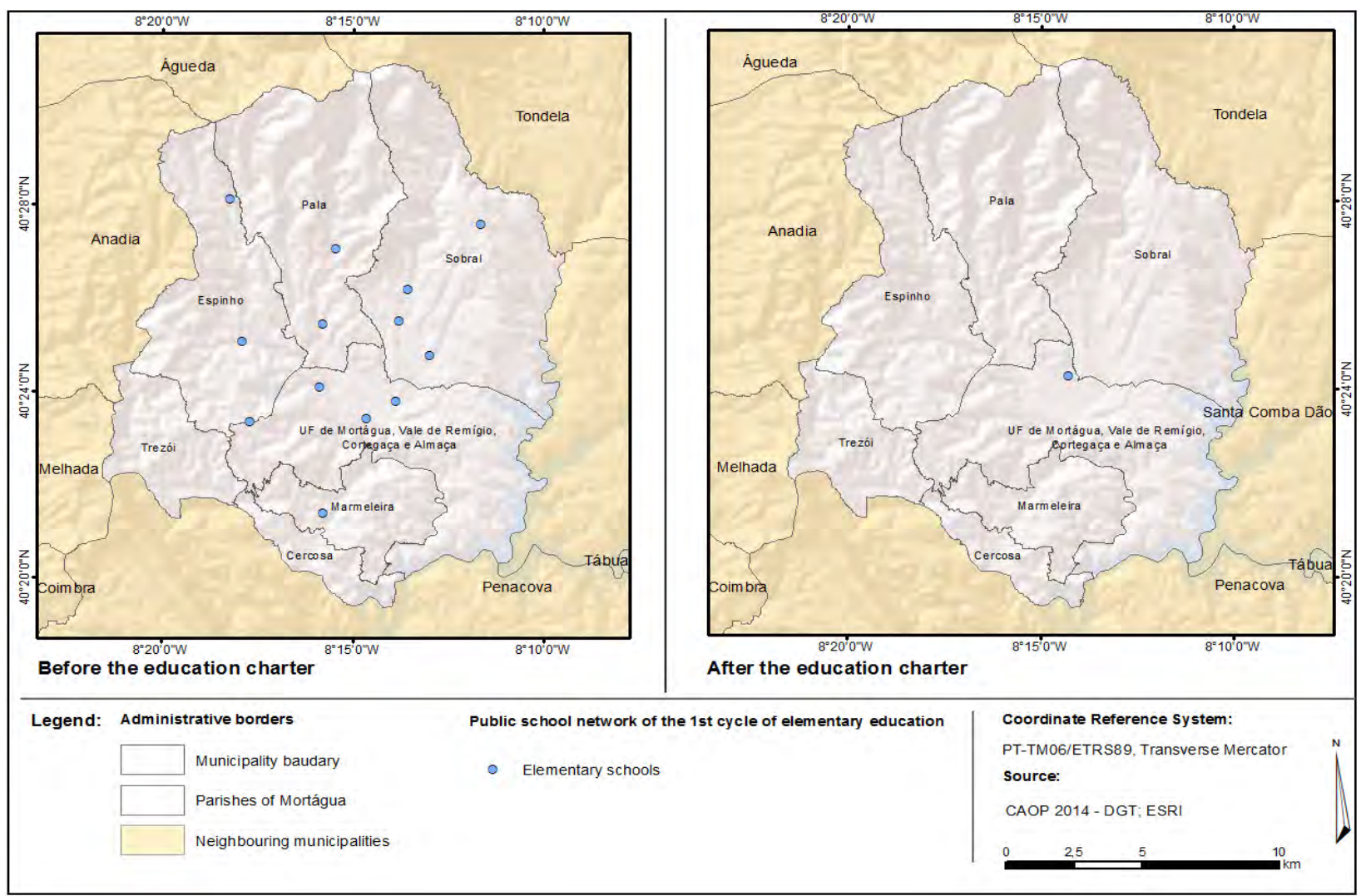

Figure 2. School network of Mortágua: (a) before the education charter; and (b) after the education charter.

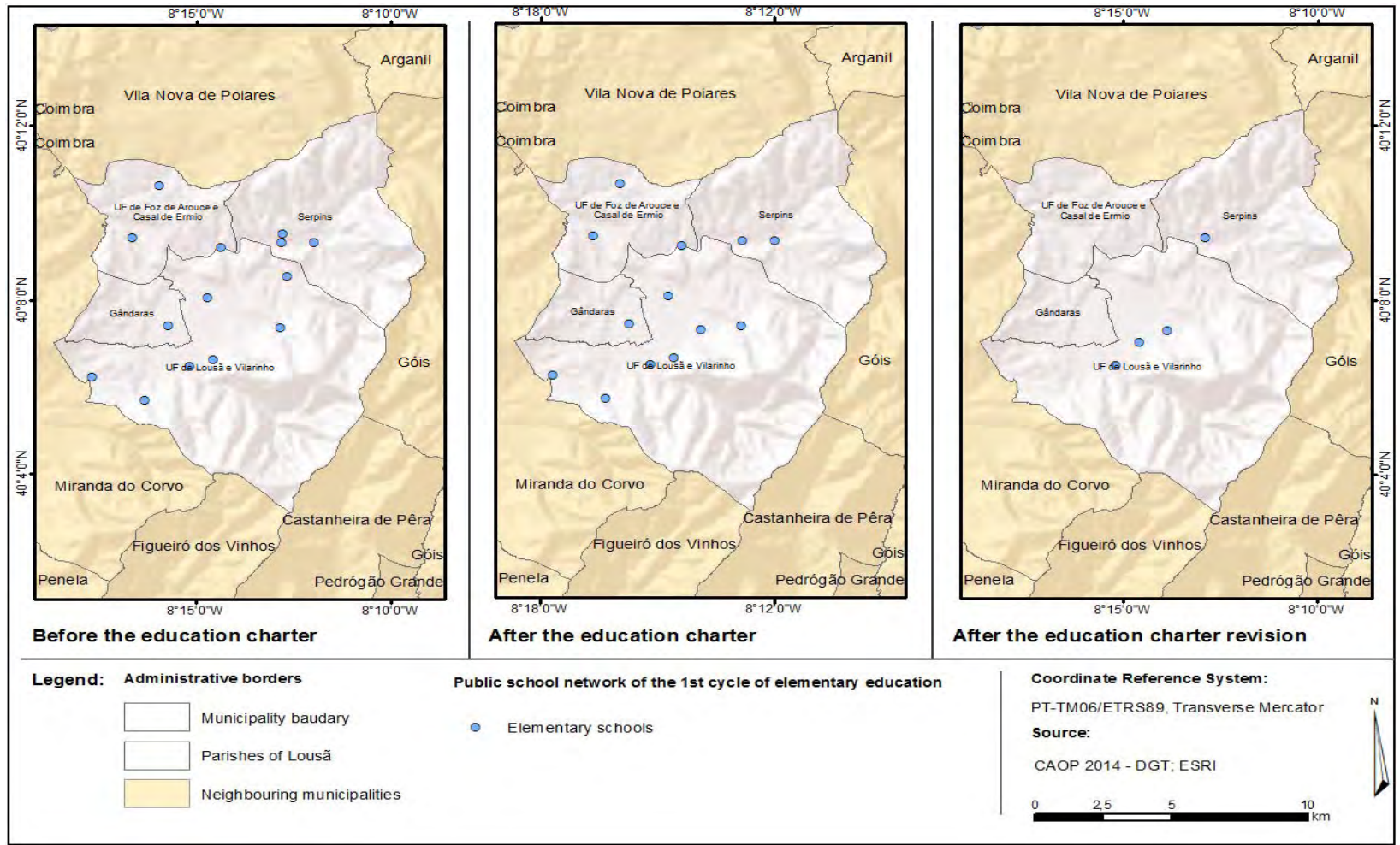

Figure 3. School network of Lousã: (a) before the education charter; (b) after the education charter; and (c) after the education charter revision. 
With a school network of much higher dimension comparing to the two previous examples ( 59 schools), in the municipality of Figueira da Foz the school network reorganization proposal submitted by the education charter followed an intervention strategy phased and based on the definition of 10 educational territories, which were used to support the school network planning, although some had more than one school (Faculdade de Letras da Universidade de Coimbra, 2006). Based on these assumptions, at the final phase, it was proposed the creation of nine school centers (mostly by conducting rehabilitation and extension works) and the maintenance of seven schools (only two with the implementation of rehabilitation works), with the necessary closures planned to occur gradually, according to the physical conditions and the natural dynamics of each school (see Figure 4).

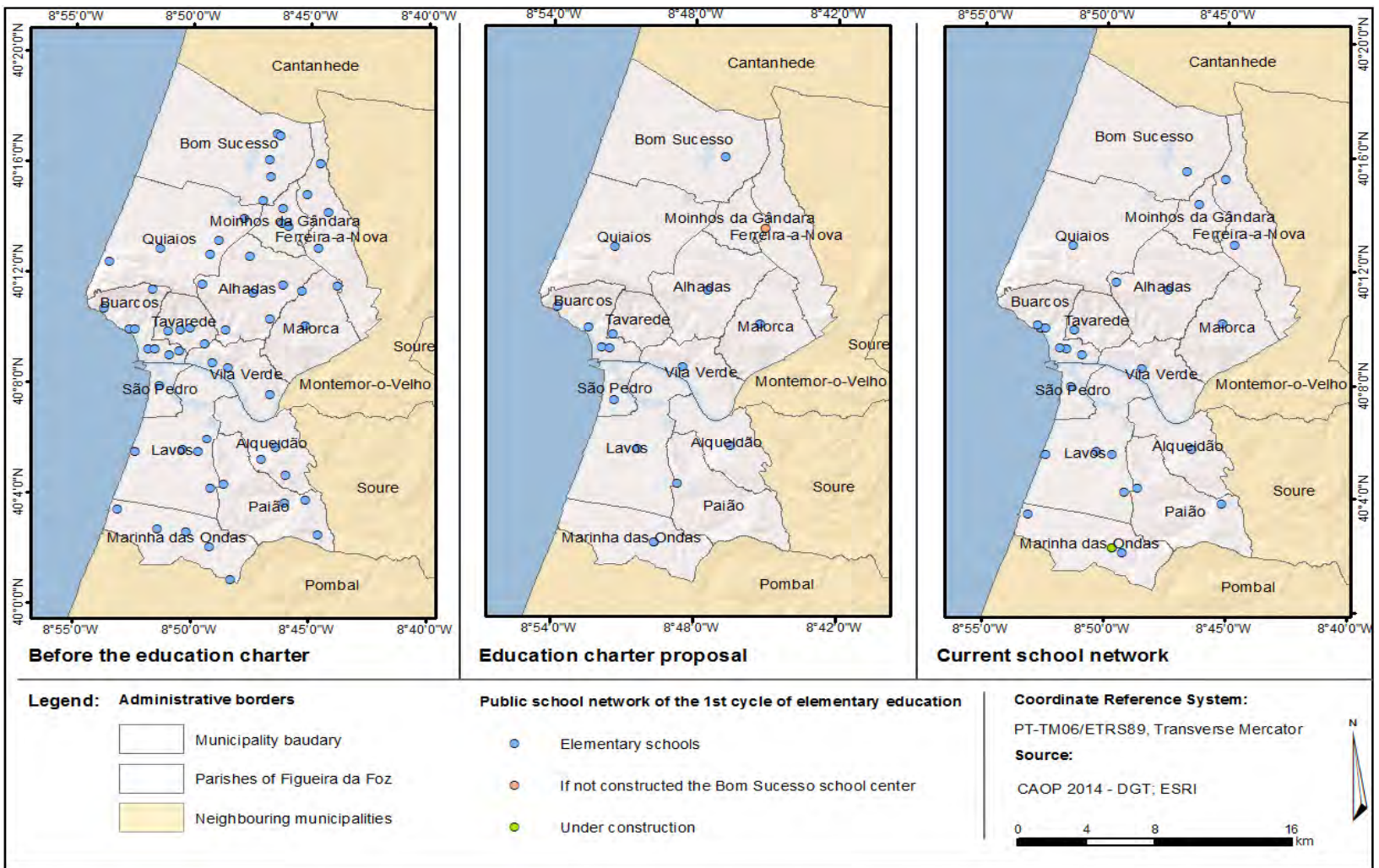

Figure 4. School network of Figueira da Foz: (a) before the education charter; (b) education charter proposal; and (c) current school network.

Although the school network of the municipality of Figueira da Foz had suffered a much more significant reduction than the one observed in the municipality of Lousã, largely due to its natural dynamics, which determined a later closure of schools of small dimension, in both cases the geographic distribution and typology of the school network did not suffer significant structural changes with the reorganization of the school network proposed by the education charter. They bet on a proximity school network, with the maintenance in operation of schools of small dimension, not having a significant increase in the number of moving students, neither a strong investment in the school center typology (Cordeiro, Martins, \& Ferreira, 2014). Thus, it was not ensured the creation of equal access conditions to a quality education for all the students in these two municipal territories. The reorganization of the school network adopted seems to match the "community" type, which occurs when the claims of local actors overlap or ignore the criteria and objectives defined centrally (Cordeiro \& Martins, 2013; Cordeiro, Martins, \& Ferreira, 2014). 
After almost a decade since the completion of the education charters, the scenario is quite different in the three municipalities under analyses. While, in the municipality of Mortágua, the reorganization of school network remains perfectly adjusted and there is no need to review the submitted proposals; in the two other municipalities, the reality is quite different. In the municipality of Lousã, the lack of investment in education and noticeable strategic vision in the proposal submitted on the education charter led to an unsustainable situation of an inadequate school network and increasing school failure. Given the awareness of the urgency to provide new opportunities to young students of the municipal territory, the municipality reacted and initiated a review process. Completed in 2015, the programming criteria now followed were completely distinct from the initials criteria, having chosen to follow the national movement of modernization of the school network, which, in practice, has resulted in the concentration of the school population in four schools and in the closure of the others (nine schools). In the opposite situation, the municipality of Figueira da Foz continues using the education charter passed in 2006 as a guiding educational policy document, which had a very low degree of implementation. Only one school center has been built, in the urban center, with the closing of some schools of small dimension. Specific works of rehabilitation and extension of schools were also carried out, but were limited to classrooms, ignoring the need to equip buildings with additional support spaces.

The results of this comparative study lead us to realize that we should not be tempted by simplistic interpretations. In a purely empirical analysis, we would be compelled to believe that the discrepancies found in the level of school system reorganization proposals would be related to the different territorial contexts and that the most dynamic municipalities would be the ones to show greater concern for the modernization of the school network. In a more elaborated analysis, based on real cases, it can be shown that the differences observed are related to political reasons, either party-political families, which can approach or deviate local authorities from the national guidelines, or strategic vision that can interfere with the definition of goals and objectives for local education policy. Very often, these issues can be overcome with a quality technical team and able to influence the political decision.

But what more important than identifying and characterizing the different municipal options and understanding the reasons that led to the choice of different paths, is to realize if the type of reorganization of the school network made is reflected in the quality of education and training systems, and consequently, in the learning process of students and the goal that guides the educational resources planning.

A study conducted in 2015 by University of Coimbra for the Intermunicipal Community Region of Coimbra on school drop-out prevention and promotion of equal access to education appears to identify a relation between the type of reorganization of the school network performed and the school results of students. Of all the 19 municipalities of the Intermunicipal Community Region of Coimbra, the study reveals that the municipality of Mortágua is the one that presents the second best place in terms of the results of 4th grade national exams, followed by the municipality of Figueira da Foz, which occupies the eighth place, and the municipality of Lousã, which appears in 18th place (see Table 1). If the differences in the types of implemented educational network reorganization can explain the positioning of the municipality of Mortágua and the distancing of this municipality in relation to the other two territories, that same argument does not explain the number of rating that separates the municipalities of Figueira da Foz and Lousã. In this case, the reason seems to be the difference in demographic and socio-economic dynamism between the two territories, which, in the case of the municipality of Figueira da Foz, works as a mitigating element of the lack of investment in the modernization of the school network. The same reality can be confirmed by the analysis of the national exams 
of 4th grade according to classification (see Table 2), being the municipality of Mortágua the one that records the lowest percentage of national exams of 4 th grade with negative rating $(=$ or $<50 \%)$. Similarly, it is also the municipality that shows the lowest number of exams with bad rating $(=$ or $<35 \%)$ and the one that shows the highest number of exams with very good rating $(=$ or $>80 \%)$.

Table 1

Average of the 4th Grade National Exams

\begin{tabular}{|c|c|c|c|c|}
\hline \multirow{2}{*}{ Municipalities } & \multicolumn{2}{|c|}{ 4th grade exams } & \multirow{2}{*}{\multicolumn{2}{|c|}{ Average of 4 th grade exams }} \\
\hline & No. & $\%$ & & \\
\hline Mortágua & 110 & 1.5 & 65.7 & $2 \mathrm{nd}$ \\
\hline Figueira da Foz & 1,021 & 13.9 & 59.7 & 8 th \\
\hline Lousã & 303 & 4.1 & 54.1 & 18th \\
\hline Region of Coimbra & 7,319 & 100 & 59.4 & - \\
\hline
\end{tabular}

Table 2

Fourth Grade National Exams According to the Classification

\begin{tabular}{|c|c|c|c|c|c|c|c|c|}
\hline \multirow{3}{*}{ Municipalities } & \multicolumn{2}{|c|}{ 4th grade exams } & \multicolumn{6}{|c|}{ 4th grade exams with classification } \\
\hline & \multirow{2}{*}{ No. } & \multirow{2}{*}{$\%$} & \multicolumn{2}{|c|}{$=$ or $<35 \%$} & \multicolumn{2}{|c|}{$=$ or $<50 \%$} & \multicolumn{2}{|c|}{$=$ or $>80 \%$} \\
\hline & & & No. & $\%$ & No. & $\%$ & No. & $\%$ \\
\hline Mortágua & 110 & 1.5 & 5 & 4.5 & 14 & 12.7 & 22 & 20.0 \\
\hline Figueira da Foz & 1,021 & 13.9 & 116 & 11.4 & 292 & 28.6 & 159 & 15.6 \\
\hline Lousã & 303 & 4.1 & 45 & 14.9 & 111 & 36.6 & 36 & 11.9 \\
\hline Region of Coimbra & 7,319 & 100 & 825 & 11.3 & 1,981 & 27.1 & 1,396 & 19.1 \\
\hline
\end{tabular}

We can conclude that despite this process being based on basic principles of reducing existing asymmetries in the national territory and creation of conditions of equal access to a quality education for all students, this objective was not completely achieved and the truth is that Portugal continues to offer education at different paces.

\section{Final Considerations}

Due to the awareness of the education role in the social development and the need of monitoring society evolution, Portugal shows an increasing concern with educational resources planning by publishing rules to ensure national consistency of the educational system.

But the evidence gathered indicates that the demand for a qualitative leap for education in Portugal was often misrepresented, resulting from a reorganization of the educational network often planned not in a purely technical logic, but, above all, in a purely political logic, not always in accordance with their primary goals and therefore conducive to creating inequalities between different territories and even within the same territory.

Nevertheless, even with rarely timely responses and assumed as a priority, the educational resources planning has reacted to the complexity of educational thinking and the social forms of life, showing Portugal currently a modernized public school network of the first cycle of primary education, with new schools and typologies.

\section{References}

Alcoforado, J. L. M., Cordeiro, A. M. R., \& Ferreira, S. M. (2012). The (re)organization school's network as a reflex of the demographic, political, and geographic transformations in Portugal's last six decades. In M. J. Mogarro, \& M. T. S. Cunha (Eds.), Rituals, spaces, \& school patrimonies (pp. 5423-5435). Lisboa: Instituto de Educação da Universidade de Lisboa. 
Barreto, A. (Ed.). (2000). The social situationin Portugal 1960-1999. Lisboa: Imprensa de Ciências Sociais.

Constituição da República Portuguesa. (1976). Republic Diary, 86-Isérie.

Câmara Municipal da Lousã. (2005). Lousã education charter. Lousã: Câmara Municipal da Lousã.

Câmara Municipal de Mortágua. (2007). Mortágua education charter. Mortágua: Câmara Municipal de Mortágua.

Cordeiro, A. M. R., \& Martins, H. A. (2013). The municipal education charter as a strategic instrument for the reorganization of the school network: Changing tendencies. Geography Notebooks, 32, 339-356.

Cordeiro, A. M. R., Santos, L., \& Caridade, P. (2013). National school network reorganization and the importance of the geographic components in the methodology adopted. Geography Notebooks, 32, 323-338.

Cordeiro, A. M. R. (2014). The municipalities role in the planning and management of Portugal's school network. In M. L. Rodrigues (Ed.), 40 years of education politics in Portugal: The foundation of the education democratic system (pp. 421-444). Coimbra: Almedina.

Cordeiro, A. M. R., Martins, H. A., \& Ferreira, A. G. (2014). Municipal school-charts and the reorganization of the school network in Portugal's central region: From demographic conditions to political decision-making. Essay Magazin, 22(84), 581-607.

Cordeiro, A. M. R. (Ed.). (2015). Intermunicipal prevention program of school dropouts and promotion of equality in school acess of Coimbra's region intermunicipal community. Coimbra: Faculdade de Letras da Universidade de Coimbra.

Decree-Law No. 7/2003 of January 15th. Republic Diary, 12-ISérie-A.

Faculdade de Letras da Universidade de Coimbra. (2006). Figueira da Foz education charter. Coimbra: FLUC.

Faculdade de Letras da Universidade de Coimbra. (2015). Review of the Lousã education charter. Coimbra: FLUC.

Instituto Nacional de Estatística. (1963). Tenth general population census-tomo II. Lisboa: INE.

Law No. 46/86 of October14. Republic Diary, 237-Isérie.

Law No. 159/99 of September 14. Republic Diary, 215-ISérie-A.

Matthews, P., Klaver, L., Lannert, J., Ó Conluain, G., \& Ventura, A. (2009). Primary school's education policy 2005-2008: International evaluation. Lisboa: Gabinete de Estatística e Planeamento da Educação-Ministério da Educação.

Rodrigues, M. L. (2010). Public school can make a difference. Coimbra: Almedina. 


\title{
Women Who Have Run for U.S. President-A Historical Look at Leadership From the 1870's to the Present
}

\author{
Paul E. Kotz \\ Saint Mary’s University of Minnesota, Minneapolis, USA
}

\begin{abstract}
A historical study was conducted to determine how many women have pursued the Presidency of the United States of America (the U.S.), and the character, leadership qualities, and strengths each of them brought to the election process, and to build our country as a nation. It reviews the period from the 1870s when our first woman presidential nominee, Victoria Woodhull, put her name in contention to the present current election dynamics, exploring the challenges each of these candidates faced in pursuit of this daunting endeavor. At least 33 women have run for president of the United States, yet to this date (November, 2016), no one have been elected to the highest leadership position in the nation.
\end{abstract}

Keywords: president leadership, women candidates, history, courage, constitution, suffrage, vote

\section{Rationale for the Study}

In early 2015, I was asked by one of my students: "Has there ever been a woman nominated for president in the two major political parties?” I thought I knew the answer, but after pondering this question, I said, "I need to investigate this, because I am not truly sure.”

Second, I have tried to raise independent thinking daughters whom I believe have the capability to do amazing things in the world and work in a society that values their contributions. So, I dedicate this in part to them.

Third, my mom had a bumper sticker, which read: "Women are natural born leaders. You are a following one.” Women have had a profound impact on my growth as a man.

Fourth, to see a young girl like Macey Hensley, at the age of six, possessing a strong knowledge of our former and current presidents and proudly announcing that she wants to be in this position someday, is very inspiring and motivating to young women, and those contemplating the presidential process.

Also, I believe it is important that we research, understand, and report how far we have progressed as a nation in terms of equality, and some of the challenges we still face. In addition, it should be emphasized that I enjoy studying and communicating findings about history.

After examining the question of women who have run for president in the two major parties, we expanded the review to those individuals who were nominated in third party candidacies as well.

\section{The Declaration of Independence and Its Connection to the Constitution and the Bill of Rights}

How does the Declaration of Independence (1776) begin? When in the course of human events, it becomes

Paul E. Kotz, Ph.D., associate professor, Graduate School of Education, Saint Mary’s University of Minnesota. 
necessary for people to dissolve the Political Bands which have connected them to one another... It goes on to state:

We hold these truths to be self-evident, that all men are created equal, that they are endowed by their Creator with certain unalienable rights, that among these are... life, liberty, and the pursuit of happiness. (Declaration of Independence, 1776)

And in our Constitution (1787), "We the People of the United States, in Order to form a more perfect Union..." this was the Preamble to the Constitution. There were seven Articles in the Constitution. They included ...: (a) The Legislative Branch; (b) The Executive Branch; (c) The Judicial Branch; (d) The Relation of the States to One Another; (e) Amending the Constitution; (f) National Debts; and (g) Ratifying the Constitution. In this discussion, Part (e) is where the primary focus is. There were 27 amendments ratified by Congress.

In 1789, Congress transmitted 12 proposed amendments to the State Legislatures. Amendment 3 through 12 became the Bill of Rights adopted in 1791.

Amendments 1 and 2 respectively, were: (a) Freedom of Religion, Speech, and the Press; Right of Assembly and Petition; and (b) Right to Bear Arms.

And, what is the 19th Amendment about?_Women's Suffrage (The Right to Vote)—proposed on June 4, 1919 and ratified in August 1920. This leads into our topic connecting it with Article II, Section 1 (Art. II, Sec. 1).

Since 1789, the Constitution had never directly prohibited women for running for President. Art. II, Sec. 1 spells out the basic qualifications for office that will be listed below in the Constitution and the Presidency section.

\section{The Constitution and the Presidency}

"No Person except a natural born citizen, or a citizen of the United States, at the time of the adoption of this Constitution, shall be eligible to the office of President; neither shall any person be eligible to that office who shall not have attained to the age of thirty five years, and been fourteen years a resident within the United States.” the Article reads. However, in reality, states controlled voting requirements and major political party nominations in the early years.

\section{Women Who Have Run for President}

The focus of this presentation is party-nominated women presidential candidates and other notable individuals who pursued the presidency. In the run for the Democratic nomination for president (2008), Hillary Clinton came closest of any woman to that date to win the presidential nomination of a major political party. Clinton is not the first woman to run for U.S. President, and not even the first to run for a major party's nomination. As of 2016, Hillary Clinton is the first woman nominated by a major party, the Democratic Party.

\section{Is There a Political Agenda?}

This is not a political endorsement for the women of either major party currently running for President, nor any third party.

How have women been represented in presidential elections to date? What are the historical challenges for women running for our highest office? Has any progress been made? 


\section{Party Nominees}

No major party has ever nominated a woman for U.S. president. However, it must be noted that two women have won the nominations of major parties for vice-presidential candidates: Geraldine Ferraro for the Democratic Party in 1984 and Sarah Palin for the Republican Party in the 2008. Senator Hillary Clinton also attracted considerable support for the Democratic nomination in 2008.

Nominees are candidates nominated or otherwise selected by political parties for particular offices.

Listed as nominees or nomination candidates are those women who achieved ballot access in at least one state (or, before the institution of government-printed ballots, had ballots circulated by their parties).

At least 35 women have run for the president of the United States. Though American women haven tried, most are unknown, and some represent parties that arguably merit obscurity-including the Surprise Party. May this party name generate amusement. It is true that the women who mounted platforms to speak to their issues were courageous. Let us take a look at some of these presidential candidates, arranged chronologically by each woman's first campaign for the office, with a brief discussion of the influence of the 19th Amendment intermixed.

\section{Victoria Woodhull-1872}

In 1872, Woodhull was the first female candidate for President of the United States. She was an activist for women's rights and labor reforms. Woodhull was also an advocate of free love, by which she meant the freedom to marry, divorce, and bear children without government interference. Her occupations included suffrage activist, stockbroker, businesswoman, writer, and presidential candidate. She also played a role in the report of a sex scandal involving Henry Ward Beecher. She was also known as Victoria California Claflin, Victoria Woodhull Martin, "Wicked Woodhull," and other names. With her sister, Tennessee, they were labelled "The Queens of Finance."

While many historians and authors agree that Woodhull is the first woman to run for President of the United States, some have questioned the legality of her run. They disagree with classifying it as a true candidacy because she was younger than the constitutionally mandated age of 35 . However, election coverage by contemporary newspapers did not suggest age was a significant issue. The presidential inauguration was in March 1873. Woodhull's 35th birthday was in September 1873.

Her opposition to abortion is frequently cited by opponents of abortion when writing about first wave feminism. The most common Woodhull quotations cited by opponents of abortion are "The rights of children as individuals begin while yet they remain the fetus" (Woodhull, 1870). "Every woman knows that if she were free, she would never bear an unwished-for child, nor think of murdering one before its birth" (Dannenfelser, 2015). She also advocated, among other things, sex education, "marrying well," and pre-natal care as the way to bear healthier children and prevent mental and physical disease.

Her arrest on obscenity charges a few days before the election for publishing an account of the alleged adulterous affair between the prominent minister Henry Ward Beecher and Elizabeth Tilton added the sensational coverage of her candidacy. She did not receive any electoral votes, and there were conflicting evidences about popular votes. Many of the reforms and ideals Woodhull espoused for the working class, against what she saw as the corrupt capitalist elite, were extremely controversial in her time. Generations later, many of these reforms have been implemented and are now taken for granted. Some of her ideas and 
suggested reforms are still debated today.

Eventually, Horace Greeley (Democratic) and Ulysses S. Grant (Republican) squared off for the two major parties. Grant won, and is still remembered from the Civil War heroics of the 1860's.

\section{Belva Ann Lockwood-1884 \& 1888}

Lockwood posted two unsuccessful bids for the presidency under the National Equal Rights Party. She was thoroughly educated and did achieve her law doctorate.

Lockwood was the first woman attorney to practice before the Supreme Court of the United States. She was also the first woman to appear on official ballots as a candidate for U.S. President. She advocated for more options for women. Lockwood worked as a principal at several local schools for young women. She was then selected to head a girls' seminary in Owego, New York, where she stayed for three years. Her educational philosophy was gradually changing after she met women's rights activist Susan B. Anthony. Lockwood agreed with many of Anthony's ideas about society's restrictions on women. Anthony was concerned about the limited education that girls received. Courses at most girls' schools chiefly prepared female students for domestic life and possibly for temporary work as teachers. Anthony spoke about how young women ought to be given more options, including preparation for careers in the business world, where the pay was better. Lockwood was encouraged to make changes at her schools.

She was a competent lawyer who drafted an anti-discrimination bill. In 1872, she introduced a bill for equal pay for federal government employees. She testified before Congress in support of legislation to give married women and widows more protection under the law. Because her practice was limited in the 1870s due to social discrimination, Lockwood drafted an anti-discrimination bill to have the same access to the bar as male colleagues. From 1874 to 1879, she lobbied Congress to pass it. In 1879, Congress finally passed the law, which was signed by President Rutherford B. Hayes. It allowed all qualified women attorneys to practice in any federal court. Lockwood was sworn in as the first woman member of the U.S. Supreme Court bar on March 3, 1879. Late in 1880, she became the first woman lawyer to argue a case before the U.S. Supreme Court. Lockwood has been remembered in many ways.

In 1908, Syracuse University gave Lockwood an honorary law doctorate. A portrait of her at the time of that occasion hangs in the National Portrait Gallery in Washington. During World War II, a Liberty Ship was named the Belva Lockwood. In 1986, she was honored with a postage stamp as part of the Great Americans series.

Women could not vote at that time, yet we had candidates that were eligible.

Representing a third party without a broad base of support, Lockwood did not have a serious chance of winning the presidency, and Notable American Women stated that she received about 4,100 votes.

Since women could not vote, and most newspapers were opposed to her candidacy, it was unusual that she received any votes. In an 1884 article, the Atlanta Constitution referred to her as "Old Lady Lockwood" and warned male readers of the dangers of "petticoat rule."

In 1884, Grover Cleveland (Democrat) became president, and in 1888, Benjamin Harrison (Republican) beat out Grover Cleveland.

\section{The 19th Amendment}

By September 1920, the 19th Amendment giving all women the right to vote had been ratified, but it 
would take another two decades for the next significant female presidential candidate to emerge. Although Americans think of us as the leader in all things progressive, the fact is that 26 countries had granted women the rights for vote before the U.S. did, and the same is true of electing women as national leaders. The U.S. falls behind many others including Australia, Britain, Canada, Germany, India, Ireland, Israel, and even Pakistan, in setting this precedent. The 19th Amendment provided new hope for female candidates in the presidential arena.

\section{Laura Clay-1920}

“I am a Jeffersonian Democrat.” In 1920, Laura Clay founded the Democratic Women’s Club of Kentucky.

At the same year, she was a delegate to the Democratic National Convention. Her name was placed in nomination for President. She worked after 1920 for repeal of the 18th Amendment (prohibition), even though she herself was a teetotaler and a Women's Christian Temperance Union (WCTU) member. Laura Clay supported women's equal rights to education and vote. At the same time, she believed that Black citizens were not yet developed enough to vote.

She did support, in principle, that educated women of all races get the rights to vote, and spoke at times against ignorant White voters. She contributed to an African American church project aimed at self-improvement. Also, she supported states' rights and the idea of White superiority, and feared federal interference in Southern states' voting laws.

\section{The Surprise Party-1940}

In 1940, Gracie Allen announced she was running for President of the United States on the Surprise Party ticket. Burns and Allen did a cross-country whistle-stop campaign tour on a private train, performing their live radio show in different cities. In one of her campaign speeches, Allen said, "I do not know much about the Lend-Lease Bill, but if we owe it we should pay it.” Another typical Gracie-ism on the campaign trail went like this, "Everybody knows a woman is better than a man when it comes to introducing bills into the house." The Surprise Party's mascot was the kangaroo, and their motto was that "It is in the bag."

\section{Three Candidates-1952}

This period saw a dearth of candidates running for office, in part due to the immense popularity of Ike. Ellen Linea W. Jensen from the Washington Peace Party, Mary Kennery from the American Party, and Agnes Waters from American Woman's Party all were third party nominees. You may recall that after Harry Truman (1948 President) finished office, Republican Dwight Eisenhower beat Adlai Stevenson and took power in 1952 and again in 1956.

\section{Margaret Chase Smith-1964}

In 1964, Margaret Chase Smith arrived on the scene with a combination of poise and vigor. Margaret served as a Republican Senator from Maine, the first woman elected to both the House of Representatives and the Senate. At the 1964 Republican National Convention, she became the first woman to have her name placed in nomination for president at a major party's convention. She was also known for her opposition to Senator Joseph McCarthy's investigation tactics. She did not receive the nomination of her party, and Barry Goldwater earned the nomination. 
Margaret was famous for her wit and wisdom. "When people keep telling you that you can not do a thing, you kind of like to try it." "Leadership is not manifested by coercion, even against the resented. Greatness is not manifested by unlimited pragmatism, which places such a high premium on the end justifying any means and any measures." "One of the basic causes for all the trouble in the world today is that people talk too much and think too little. They act impulsively without thinking. I always try to think before I talk." "My creed is that public service must be more than doing a job efficiently and honestly. It must be a complete dedication to the people and to the nation with full recognition that every human being is entitled to courtesy and consideration, that constructive criticism is not only to be expected but sought, that smears are not only to be expected but fought, that honor is to be earned, not bought."

She took a stance on Senator Joe McCarthy's tactics, "As a United States senator I am not proud of the way in which the Senate has been made a publicity platform for irresponsible sensationalism” (Lewis, 2015). "I do not want to see the Republican Party ride to political victory on the Four Horsemen of Calumny-Fear, Ignorance, Bigotry, and Smear."

In the end that year, Lyndon Johnson (Democrat) along with Hubert Humphrey defeated Barry Goldwater for the presidency.

\section{Charlene Mitchell-1968}

Charlene was an African-American international socialist, feminist, labor and civil rights activist, and formerly a member of the Communist Party USA, which she joined at age of 16 . She emerged as one of the most influential leaders in the party from the late 1950s to the 1980s. She now belongs to the Committees of Correspondence for Democracy and Socialism.

Charlene's early civil rights activism included organizing, in 1943 at the age of 13, both Black and White teenagers in pickets and other actions at the Windsor Theatre in Chicago, which segregated Black customers in the balcony, and also at a nearby segregated bowling alley. The lack of success of picketing and leafleting led the young Charlene to organize another action for her group of activists, who took the name of American Youth for Democracy. This group held a sit-in at the Windsor, with White members going up to the "colored-only" balcony while Black members took their seats in the auditorium's "whites-only" section below. Nixon and Spiro Agnew ended up defeating Hubert Humphrey and Edmund Muskie in this election cycle.

In 1972, four noteworthy candidates announced their candidacy, and all merit a description of their respective bids.

\section{Shirley Chisholm-1972}

In 1972, Chisholm became the first woman to run for the Democratic presidential nomination as well as the first major party Black candidate. She came in fourth at the convention where George McGovern won the Democratic nomination.

"We live in revolutionary times." "The shackles that various groups have worn for centuries are being cast off. This is evidenced by the 'developing' nations of the world, which we consider, for the most part, underdeveloped." "Countries such as India, Ceylon, and Israel have women for Prime Ministers and in other decision-making positions. American women must stand and fight—be militant even—for rights which are ours." 
Her bid for the presidency was referred to as the "Chisholm Trail," and she won a lot of support from students, women, and minority groups. She entered 11 primaries and campaigned in several states, particularly Florida, but with little money, it was difficult to run an aggressive campaign. Overall, people in 14 states voted for Chisholm for President. After six months of campaigning, she had 28 delegates committed to vote for her at the Democratic Convention. Although she did not win the nomination, she received 151 of the delegates' votes.

\section{Patsy Takamoto Mink-1972}

In 1972, a group of Liberal Democrats in Oregon asked Mink to be their presidential candidate, and she was on the ballot in Oregon's May primary. Mink received just $2 \%$ of the vote, coming in eighth out of nine candidates.

She was the first woman of color to serve in the United States Congress, but it was the work that she did there that should be remembered. Mink represented many groups that, prior to her election, had been absent from national politics, working tirelessly to serve women, minorities, and the poor. She brought attention to issues that others ignored.

\section{Linda Jenness-1972}

She was involved in the case 26 F.C.C.2d 485 (1970), regarding media coverage of third-party candidates, which was not present at her time of running for office. Aged 31 at that time of the election, she did not meet the Constitutional age requirement to hold the office of President, but the Socialist Workers Party (SWP) was on the ballot in 25 states-six more than in 1968. She was qualified for the Ohio ballot but removed when she could not prove she was 35. As of September 2010, Linda Jenness was still active as supporter of the SWP.

\section{Evelyn Reed-1972}

Member of the American Trotskyist movement, socialist feminist, and one of the first to challenge anthropological and other spurious justifications for patriarchy, Reed was nominated as a candidate for President of the United States for the Socialist Workers Party in the United States presidential election, 1972. On the ballot in only three states (Indiana, New York, \& Wisconsin), she received a total of 13,878 votes. She came in second to Linda Jenness, with 37,423 votes. Reed (1972) noted:

The woman question can only be resolved through the lineup of working men and women against the ruling men and women. This means that the interests of the workers as a class are identical; and not the interests of all women as a sex. Ruling-class women have exactly the same interests in upholding and perpetuating capitalist society as their men have. Thus, the emancipation of working women will not be achieved in alliance with women of the enemy class, but just the opposite; in a struggle against them as part and parcel of the whole class struggle.

In 1972, Nixon and Agnew defeated George McGovern and Sargent Shriver.

\section{Margaret Wright-1976}

Wright was a shipyard worker during World War II, and one of the principals of the film The Life and Times of Rosie the Riveter. Her ticket was also endorsed by the Peace and Freedom Party. Bumper stickers advertised her as a "Socialist for President." The ticket received 49,016 votes (0.06\%). Wright was also a founder and activist of Women against Racism in the Watts section of Los Angeles. 


\section{Ellen McCormack-1976}

As a representative for the rights to Life Party, she received 22 votes at the Democratic convention, but won by Jimmy Carter. "Abortion is put forth as a solution for the poor, but I think the poor want better housing, more jobs and food on their tables. I do not think aborting their babies makes them any happier. I think it probably contributes to their misery.”

McCormack made the decision to run just three years after the U.S. Supreme Court's 1973 Roe v. Wade decision on abortion, declaring herself a candidate in the 1976 Democratic primaries for "the defense of unborn babies." Overturning the court's ruling with a constitutional amendment to ban abortion was her main focus.

Because of changes in federal election law, McCormack became the first female presidential candidate to qualify for federal campaign funding. She also was the first female candidate to receive Secret Service protection.

If you recall, in 1976, Jimmy Carter and Walter Mondale defeated Gerald Ford and Bob Dole.

\section{Right to Life Party/Peace and Freedom Party/Workers World Party-1980}

Three women ran in this year, but they did not receive much attention: Ellen McCormack, Right to Life Party; Maureen Smith, Peace and Freedom Party; Deirdre Griswold, Workers World Party.

In this election year, Ronald Reagan, together with George H. W. Bush, defeated Jimmy Carter.

\section{Sonia Johnson-1984}

Sonia Johnson was a fifth-generation Mormon who came into the political sphere when the Mormon Church spoke out against the Equal Rights Amendment (ERA). An English professor and mother of four, she knew little about it until she became "uneasy" that her church was "opposing something with a name as beautiful as the 'equal rights' Amendment.” This eventually led Johnson to run for the presidency. Sonia Johnson from Citizens Party recorded 72,200 votes in 19 states. Johnson (1984) remarked:

I am a feminist to the core and will be until I die... fiercely, passionately, reverently, and totally committed to justice for my sisters on this earth. I feel, frankly, as if I had been born in this time because I have always felt this way-even in the preexistence. This is the right time for me. I feel as if I have come home.

Gavrielle Holmes from Workers World Party also ran that year. But, once again, Ronald Reagan defeated Walter Mondale and Geraldine Ferraro.

\section{Patricia Scott Schroeder-1988}

Here is a glimpse into the mindset of Schroeder, "Imagine a picture of the House floor of 406 women and 28 men or the Senate floor with 98 women and two men.” In 1972, Schroeder became the first congress woman. Her quarter-century career there made her the all-time leader on women's issues, and her campaign for the 1988 presidential election was based on her belief that "America is man enough to back a woman."

As co-founder of the bi-partisan Congressional Caucus for Women's Issues and as Democratic Whip, Schroeder became the lead sponsor of the Equal Rights Amendment, as well as other legislation to secure women's rights in employment, education, and finance. Her strong sense of humor was reflected in her response to inquiries about running as a woman, "What choice do I have?” She reflected that more women would run for office if they only knew their history and could make realistic use of these stepping stones. 
Schroeder found firm support among feminists for her 1988 presidential campaign—but not enough to win the Democratic nomination that went to Michael Dukakis. She came closer than any woman thus far, coming in third in a June 1987 Time poll. National Organization for Women (NOW) pledged \$400,000, enough for her to qualify for federal matching funds, and Schroeder visited 29 states during 1987. Ever practical, her motto from the beginning was "no dough, no go," and when she could not raise sufficient money to compete against better-funded men, she ended her campaign that autumn.

\section{Lenora Fulani-1988}

Under the New Alliance Party, Lenora Fulani stated, "In unity lies power... There are millions of Americans looking to come together, looking to create this new force... changing the political culture (so that) not just money and top-down forces speak. I think our democracy is on the decline, because of the influence and corruption of the two-party system.”

Lenora Fulani combined a career as a psychologist with a life of activism. She explained, "I identify very strongly with the outsiders. I am a leader who has chosen to be outside corporate America and inside the real mainstream—with my people and other outsiders.”

In this year, George H. W. Bush and Dan Quayle defeated Michael Dukakis and Bentsen.

\section{From 1992 to 2008}

From the period of 1992 to 2008, female candidates came from parties, such as the New Alliance Party, Socialist Equality Party, Looking Back Party, Workers World Party, Peace and Freedom Party, Socialist Party, Liberty Union Party, The American Party, Independent Party, Green Party, and the Party for Socialism and Liberation.

They never fully got traction as third parties with Clinton and Gore defeated George H. W. Bush in 1992. In 1996, Clinton Gore defeated Dole and Kemp.

Elizabeth Dole is a noteworthy republican candidate in 2000, who generated a great deal of admiration and following.

\section{Elizabeth Hanford Dole-2000}

"Women share with men the need for personal success, even the taste of power, and no longer are we willing to satisfy those needs through the achievements of surrogates, whether husbands, children, or merely role models." Elizabeth Hanford Dole was voted as "most likely to succeed” by her high school class, an astute prediction. The first woman to serve in two different Cabinet positions under two presidents, she ran for the Republican nomination in the presidential election of 2000.

After graduating from law school, at the encouragement of Senator Margaret Chase Smith, Hanford joined Richard Nixon's administration as an assistant on consumer affairs, and he appointed her to the Federal Trade Commission shortly before he left office in 1973. She wed Kansas Senator Robert Dole in 1975; he was divorced, and they never had children.

When Democrats won the White House in 1976, Elizabeth Dole was out of office until 1983, when Ronald Reagan appointed her to head the Department of Transportation. The department was less than twenty years old at the time, and she was the first woman to hold the top position. She withdrew after a seven-month effort, when she had raised only $\$ 4.7$ million compared to George W. Bush’s \$57 million. 
Some pointed out that her lack of support resulted from the fact that Dole rarely reached out to feminists during her career. Her poll numbers showed a particular lack of appeal to younger women. Statistical analysis of media coverage confirmed that she, too, was a victim of the old habit of focusing on personal qualities with female candidates, not on their issues. Dole's campaign may have reinforced this idea. She often left the stage to interact with audiences, a method that audiences loved—but which also allowed reporters to emphasize her style over substance.

In 2000, George W. Bush and Cheney defeated Gore and Lieberman.

\section{Carol Moseley-Braun-2004}

Carol Moseley-Braun (Democrat) was elected to the Senate in 1992, which was considered the "Year of the Woman," as many angry female voters came out to show their disagreement with the outcome of the Clarence Thomas-Anita Hill proceedings. She became the first African American woman elected to the United States Senate, the first African American senator to be elected as a Democrat, and the first woman elected to the Senate from Illinois.

She graduated from the University of Chicago with a law degree and joined the Justice Department. Three years later, after being recruited by neighbors, she was elected to the Illinois House. In 1991, she ran for the Senate in Illinois. Illinois often votes Republican. However, Women All over America sent donations to help her defeat the Republican nominee, and she won 53\% of the vote. The "Year of the Women" had mixed results elsewhere, but Carol Moseley-Braun was its best exemple. On September 11, 2003, she announced her run for the presidency at Howard University in Washington, D.C.. While acknowledging that it might be a "long-shot," she did not think that this meant she could not win, and argued that her experience in local, state, national and international government made her a well-rounded candidate.

Many feminists were disappointed in Mosely-Braun's Senate tenure, and some African Americans urged her to step down in favor of Black activist Al Sharpton. Yet when television journalist Diane Sawyer asked why she did not support another candidate who had a "real shot at victory," she replied that her record was as strong as that of some male candidates: John Edwards had yet to stand for re-election; Howard Dean led a state with fewer residents than Cook County; and Al Sharpton had never held elective office.

Like other female candidates, Moseley-Braun found it difficult to raise money, and her well-publicized effort to get on the Virginia ballot by petition did not collect enough signatures. On January 15, 2004, four days before the Iowa caucuses, she dropped out on Jon Stewart's Daily Show.

In this election cycle, Bush and Cheney defeated John Kerry and John Edwards.

\section{Hillary Rodham Clinton-2008}

Hillary Clinton wrote to NASA as a child inquiring how to become an astronaut. NASA replied that girls could not be astronauts. At the Grade 9, Hillary would sometimes come to class wearing her Girl Scout uniform. Perhaps not coincidentally, she would later promote school uniforms. How Hillary met Bill Clinton at Yale: She got up from her desk, walked over to him, extended her hand, and said, "If you keep looking at me, and I am going to keep looking back, we might as well be introduced. I am Hillary Rodham.” When she was a teenager, Hillary organized a baby-sitting group to look after the children of migrant Mexican workers in rural Illinois.

She was determined to meet her goals, and she has come closest of any female candidates to date and receive the nomination of a major party. 
Clinton received more than 17 million votes during the Democratic National Convention, but trailed Barack Obama by 103 delegates at the final tally. Hillary was the first First Lady to hold a postgraduate degree, according to Yale Law (1973) and run for and be elected as a senator of New York in 2000. She broke through the cash ceiling for women by raising more than $\$ 212$ million. Fund raising has always been the biggest impediment to women candidates. Clinton's 18-month campaign with intense media coverage may inspire more women to seek elective office.

\section{Cynthia McKinney-2008}

Running under the Green Party platform, Cynthia McKinney tallied 161,603 votes. She lamented in her plight as a Black female candidate, “They look at me, they see a Black woman, they say, She has got to be another Maxine Waters (a fiery Liberal from Los Angeles). Well, heck, I do not mind being another Maxine Waters when it comes to the strength and force of advocacy. But to judge me in my entirety by what I look like is quite base."

In 2008, President Obama and Joe Biden received the nomination and defeated John McCain and Sarah Palin.

\section{Jill Stein-2012}

Jill is the most successful third-party female Presidential candidate, in terms of aggregate votes in a general election. It should be noted that Rosanne Barr also ran for the Green Party nomination, but did not receive the nomination. Michele Bachman from the Republican Party ran a very competitive campaign, but withdrew in January of 2012. Obama and Biden again won this election, and this time overed the team of Mitt Romney and Paul Ryan.

\section{Why do Third Parties Have Such a Difficult Time Getting Going?}

Jill Stein is an excellent example of a third party candidate, who has a very good following of potential voters. Yet, the third party candidates are at a disadvantage because of federal campaign finance laws and rules dictating who can enter presidential debates and a lack of media attention. In addition, a significant amount of paperwork is required to become a viable candidate. When Ralph Nader announced in February 2004 that he would seek the presidential nomination, he was required to collect 1.5 million signatures in all states to appear on the ballot. Deadlines for those signatures begin as early as May 2004. Campaign finance rules say that a political party can only get government funding to run a race, if it has received a certain percentage of votes from the previous election.

\section{Carly Fiorina and Hillary Clinton-2016}

Thoroughly educated in Business Administration and Marketing, Carly Fiorina has served in executive positions for American Telephone and Telegraph Company (AT\&T) and that company's spinoff, Lucent. Most prominently, she held the role of chief executive officer (CEO) of Hewlett-Packard from 1999 to 2005. She continues to participate in getting her message out and remains in the race as of this writing. As mentioned earlier in the 2008 section, Hillary Clinton continues to be the strongest force for the Democratic Party in 2016 and now is the first woman to be nominated president in this election cycle. 


\title{
Who Are the Current Women Candidates Who Ran in 2016? ${ }^{1}$
}

\author{
Democrats: Hillary Clinton-(19) \\ Republicans: Carly Fiorina; Shawna Sterling-(38) \\ Independent: Samm Tittle; Lynn Sandra Kahn; and Tami Stainfield—(21) \\ Green Party: Jill Stein-(1) \\ Libertarian: Joy Waymire-(6)
}

\section{Conclusion}

In this historical investigation of women who sought after the presidency, from the first candidate of Victoria Woodhull in the 1870's to the myriad individuals who are in the running in 2016, it is clear that women possess the character, leadership qualities, and acumen to achieve this goal in the United States. It remains to be seen if a female candidate will reach the office of the presidency in 2020 and beyond.

\section{References}

Callaway, A., \& Maurer, E. L. (2015). First but not the last: Women who ran for presiden. Washington, D.C.: The National Women's History Museum and The Shana Alexander Charitable Foundation.

Dannenfelser, M. (2015, November 4). The suffragettes would not agree with feminists today on abortion. Time.

Declaration of independence. (1776). U.S.: Congress.

DeGregorio, W. A. (2005). Complete book of U.S. presidents (6th ed.). New York: Barricade Books, Inc.

Dubois, E. C. \& Dumenil, L. (2012). Through women's eyes: An American history with documents. Publisher: Bedford/St. Martin's.

Dworkin, A. (1987). Occupation/Collaboration. And the truth shall make you free. Intercourse (Chapter 7).

Freeman, J. (2007). The women who ran for president. New York, N.Y.: Penguin Books.

Gabriel, M. (1998). Notorious Victoria. In Algonquin books of Chapel Hill (p. 12). ISBN 1-56512-132-5. Retrieved June 9, 2015, from https://kennethharperfinton.me/2016/07/30/the-first-woman-candidate-for-u-s-president-victoria-woodhull/

Goldsmith, B. (1998). Other powers (p. 20). New York, N.Y.: Alfred A. Knopf. ISBN 0394555368.

Johnson, G. W. (1956). Dynamic Victoria Woodhull. American Heritage, 7(4).

Kemp, B. (2016). Free love' advocate Victoria Woodhull excited Bloomington. In The pantagraph. Retrieved April 13, 2016, from http://www.pantagraph.com/news/local/free-love-advocate-victoria-woodhull-excited-bloomington/article_2c2cb275 -b36e-5a6a-bc6a-dd4821121900.html

Kullmann, S. (1997). Legal contender... Victoria C. Woodhull, first woman to run for president. Retrieved May 29, 2009, from http://www.feministgeek.com/teaching-learning/woodhull/

Lewis, J. J. (2015). Women who ran for president. Retrieved January, 2015, from http://womenshistory.about.com/od/public officials/tp/ran_for_president.htm

Mandel, R. B. (2007). She's the candidate: A woman for president. Retrived from http://www.bing.com/search?q=Mandelfrom, +R.+B. B.+(2007). +She\%E2\%80\%99s+the+candidate.+A+woman+for+President\&src=IE-SearchBox\&FORM=IESR02

Messer-Kruse, T. (1998). The yankee international: Marxism and the American reform tradition, 1848-1876 (pp. 2-4).

NCC Staff. (2015, April 13). Women other than Hillary Clinton who've run for president. Constitution Daily.

Shearer, M. L. (2015). Frequently asked questions about Victoria Woodhull. Retrieved January 5, 2015, from http://www.victoria-woodhull.com/faq.htm\#who

The American Presidency Project. (2015). Retrieved January 20, 2015, from http://www.presidency.ucsb.edu/

Underhill, L. B. (1996). The woman who ran for president: The many lives of Victoria Woodhull (p. 24). United States: Penguin Books. ISBN 0-14-025638-5.

\footnotetext{
${ }^{1}$ The number next to each party in parentheses indicates the total number of candidates (men and women) running for 2016. This is subject to change as we get closer to the election. At the time of this writing, Secretary of State Hillary Clinton lost in the Electoral College vote, but did win by a slim margin in the popular vote (November, 2016).
} 
Victoria, C. W. (1871, November 20). A speech on the principles of social freedom, delivered in Steinway Hall. New York, N.Y.: Woodhull \& Claflin.

Wight, C. H. (1903). Genealogy of the Claflin Family, 1661-1898. New York, N.Y.: Press of William Green.

Woodhull, V. (1870, December 24). Victoria Woodhull, first woman to run for U.S. president, member of the Equal Rights Party. Woodhull's and Claffin's Weekly. 


\title{
Effects of Different-Term Acute Swimming Exercises on Oxidative Stress Parameters in Rat Cerebellum Tissue
}

\author{
Öznur AKYÜZ \\ Celal Bayar University, Manisa, Turkey
}

\begin{abstract}
Background: Regular physical activity may prevent the onset of a large range of pathological conditions, from heart diseases to mental disorders (depression, anxiety, panic disorder, social phobia, etc.), ischemia, and neurodegenerative diseases. Although beneficial effects of exercise are not known exactly for molecular mechanisms, several hypotheses have been proposed about this research. The purpose of this study is to examine the acute effects of oxidative stress parameters on the cerebellum tissue of the different swimming exercises.

Methods: Telve week-old male Albino Wistar rats $(n=32)$ were used in this study. Rats were divided randomly into four groups: control, short-term exercise (15 mins.), moderate-term exercise (30 mins.), and long-term exercise (60 mins.) group. Glass tank containing water for swimming exercise ( $\mathrm{L} \times \mathrm{W} \times \mathrm{H}, 100 \times 50 \times 50 \mathrm{~cm}$ ) was used as pool.

Results: The differences among superoxide dysmutase (SOD), glutathione (GSH), and malondialdehyde (MDA) were studied. When the difference were examined between SOD levels, short-term and moderate-term exercise groups were statistically significant different from other groups $(p<0.05)$. When GSH levels were examined, moderate-term and long-term groups were statistical different than other groups $(p<0.05)$. When MDA levels were examined, all exercise groups being compared with the control group had statistically significant differences $(p<0.05)$.
\end{abstract}

Conclusions: SOD, GSH, and MDA levels were found to be higher in the moderate-term exercising rat's cerebellum tissue compared to rats that other groups.

Keywords: cerebellum tissue, swimming exercise, oxidative stress

\section{Introduction}

Regular physical activity may prevent the onset of a large range of pathological conditions, from heart diseases (Duruturk, Tonga, Karatas, \& Doganozu, 2015) to mental disorders (depression, anxiety, panic disorder, social phobia, etc.) (Zschucke, Gaudlitz, \& Ströhle, 2013), ischemia, and neurodegenerative diseases (Nakae \& Tsushima, 2014). Although beneficial effects of exercise are not known exactly for molecular mechanisms, several hypotheses have been proposed about this research. Increasing physical activity and muscle contractions during exercise and metabolic activity accelerates energy consumption significantly. Depending on the metabolic activity of the mitochondrial electron leakage from oxygen and electron transport chain used is increasing. After all, many reactive oxygen species comes to light. This increases lipid

Öznur AKYÜZ, Ph.D., associate professor, Department of Sports Health, School of Physical Education and Sports, Celal Bayar University. 
peroxidation (Gleeson \& Bishop, 2000). Formation of reactive oxygen species (ROS) and many defense mechanisms got advanced in the body to prevent damage caused by them. Lipid peroxidation is a process generated naturally in small amounts in the body, mainly by the effect of several ROS. These ROS readily attack the polyunsaturated fatty acids of the fatty acid membrane, initiating a self-propagating chain reaction. The destruction of membrane lipids and the end-products of such lipid peroxidation reactions are especially dangerous for the viability of cells, even tissues (Mylonas \& Kouretas, 1998).

In addition to the fact that physical exercise has numerous benefits on health, there are also findings that formation of ROS and free radicals increases particularly during intensive exercise and oxidative damage occur in muscles, liver, blood, and other tissues (Kaur \& Kapoor, 2001). Performance is dependent on anaerobic power in exercise, which is performed physiologically at maximum effort, i.e. high intensity for a short duration (Pikulski \& Brodbelt, 2003).

\section{Literature Review}

Positive effects of exercise on human health are accepted and the importance of integration of sports in our daily life is increasing day by day. Getting fit through exercise contributes to reduction in the risk of developing diseases, such as cardiovascular diseases, chronic respiratory tract diseases, diabetes mellitus, obesity, cancer, osteoporosis, and psychological disorders and anxiety, and also to taking symptoms of diseases under control. In addition, exercise increases burning of excess fat in body, helps to reach the ideal body weight by losing weight, strengthens muscles, increases blood flow, energy, circulation, bone density and self-confidence, and makes the person feel better.

The higher the exercise density, the more formation of free radical occurs (Rice, Miller, Bolwell, Bramley, \& Pridham, 1995). Production of free radicals in rat musculoskeletal and myocardium tissue homogenates was observed to have increased following single consumer treadmill exercise. During the exercise, production of free radicals increases in parallel to the increase in oxygen consumption. Acute exercise causes muscular tissue damage, lipid reproduction in membranes, and formation of free radicals spectrum. In damaged tissue, phospholipase leads to proteinase enzyme activation and arachidonic acid release in cell membranes, which causes increase in production of free radical (Bando, Wakamatsu, \& Terao, 2007).

Increasing in connection with the increase of oxygen consumption, free radicals are neutralised by a defense system that contains enzymatic and non-enzymatic anti-oxidants. Exercise creates an inbalance between ROS and anti-oxidants called oxidative stress (Von, 2006). Size of the oxidative damage, which may occur during physical exercises, is determined not only by production of free radicals, but also the defense capacity of anti-oxidants. Superoxide dysmutase (SOD) and catalase (CAT) provide the first line of defense against the ROS produced during exercise. SOD (superoxide dismutase), CAT (catalase), GPx (glutathione peroxidase), and GST (glutathione-S-transferase) are among the primary anti-oxidant enzymes within enzymatic systems effective at cellular level. It is stated that an acute exercise can affect activites of these enzymes directly. Vitamin E, vitamin $\mathrm{C}$, glutathione (GSH), and flavonoids can be given as example for non-enzymatic anti-oxidants. Flanavoids are one of the largest groups of polyphenols forming through natural means. They exist in many plants. They have anti-oxidant, anti-microbial, anti-viral, and anti-bacterial properties. Flavonoids have been known as herbal pigments for more than a century. They are of polyphenolic compounds and have spreaded over all plants. In vitro studies, their anti-oxidant properties and property to catch anti-oxidants have drawn attention. Various vegetable food and beverages (fruits, vegetables, tea, cacao, and wine) are rich in flavonoids (Prior, Wu, \& Scaich, 2005). 
Anti-oxidant substances ( $\alpha$-tocopherol [vitamin E]), $\beta$-carotene, ascorbic acid (vitamin $\mathrm{C}$ ), and folic acid prevent damages stimulated by oxidation at cellular level by preventing formation of active oxygen or by cleaning the active oxygens formed, reducing Deoxyribose Nucleic Acid (DNA) deformations and peroxidations of fats and taking part in repair of damages occurring, and hence stop formation of degenerative diseases. The most important phenolic compounds of grape, which is a member of the vitaceae family, are phenolic acids, anthocyanidins, flavanol glucosides, cinnamic acit derivatives, catechines, and proanthocyanidins (Balu, Sangeetha, Murali, \& Panneerselvam 2006; Shao, Terry, Hoek, Xie, \& Wojcik, 2009; Feng, Liu, Fratkins, \& Leblan, 2005; Devi, Badanavalu, Domenico, Narayan, \& Hindupur, 2006).

Among anti-oxidants, grape seed extract (GSE) is one of the strongest known anti-oxidants. It is a mixture of similar natural flavonoids containing proanthocyanidin and having the most effective anti-oxidant activity.

It was reported that even in the absence of disease, muscle itself produces ROS, including superoxide anions (Reid et al., 1992), hydroxyl radicals (Close, Ashton, McArdle, \& Jackson, 2005), and $\mathrm{H}_{2} \mathrm{O}_{2}$ (Reid et al., 1992). The rate of ROS production increases during vigorous exercise and high-intensity exercise (McArdle, Pattwell, Vasilaki, McArdle, \& Jackson, 2005; Ferreira \& Reid, 2008). In this context, ROS and other metabolic culprits promote fatigue (Ferreira \& Reid, 2008). It is recommended that muscle mitochondrion is one of the location of ROS production in skeletal muscle (Jackson, Pye, \& Palomero, 2007) and that ROS is a most important basis for cellular oxidative damage (Brand et al., 2004). Several pathways are included in molecular signalling within the skeletal muscle. The ROS pathway is involved in contractile protein expression, angiogenesis, mitochondrial biogenesis, and other adaptations (Lira, Benton, Yan, \& Bonen, 2010). Nevertheless, it is apparent that an increase in oxygen consumption lowers the tissue oxygen tension during muscle activity (Richardson, Noyszewski, Kendrick, Leigh, \& Wagner, 1995), which leads to heightened ROS production (Zuo, Pasniciuc, Wright, Merola, \& Clanton, 2003).

Oxidative stress begins when the production of ROS is not sufficiently balanced by antioxidant species, which neutralize them (Andreazza, 2012). For example, the generation of a superoxide anion, a powerful ROS, is typically neutralized by the antioxidant enzyme SOD to protect the cell from oxidative stress. However, excessive concentrations of superoxide may overwhelm SOD and form a hydroxyl radical after reacting with water.

There are studies that show the different effects the antioxidant defense system markers of exercise (SOD, GSH, and malondialdehyde [MDA]) on the literature (Clarkson \& Thompson, 2000; Kakarla, Vadluri, \& Reddy, 2005; Finaud, Lac, \& Filaire, 2006). In this case, lipid peroxidation being found at different levels in different tissues, membrane tissue and the fat dietary fatty acids may be dependent on different levels affection. Or it can be considered that these different results stem from the intensity of the exercise, the duration of exercise, and/or the sample group. In this context, the aim of this study is to determine the effect on markers of antioxidant found in the cerebellum tissue of the acute swimming exercise at different times.

\section{Materials and Methods}

\section{Animals}

Thirty-two male rats (12 weeks old, Albino-Wistar), fed with standard laboratory chow and water that were used in this study. Animal experimentations were approved by the Ethical Committee of the Ataturk University and carried out in an ethically proper way by following the guidelines provided. 


\section{Experimental Design}

The rats used in the study were divided into four groups: the control group, short-term exercise group (15 mins.), moderate-term exercise group (45 mins.), and the long-term exercise group (60 mins.). Acute swimming exercise was performed in three training glass tanks $(100 \times 50 \times 50 \mathrm{~cm}, \mathrm{~L} \times \mathrm{W} \times \mathrm{H})$ containing water for three experimental groups.

\section{Biochemical Study}

Biochemical investigation of cerebellum tissues. After gross morphological examination, cerebellar tissues were stored at $86{ }^{\circ} \mathrm{C}$. A $100 \mathrm{mg}$ of tissues from each rat was perfused with phosphate buffered saline (PBS)/heparin and then homogenized in a specific homogenate tampon on ice by ultra-turrax after grinding in liquid nitrogen. Then they were centrifuged according to the manufacturer's instructions. For biochemical analysis, SOD activity and MDA and GSH levels from each supernatant were measured in duplicates with a sensitive kit (Cayman-706002, USA), and Cell Biolabs-STA-330 and 312 (USA), respectively, specifically designed for rat tissue. The protein concentrations were determined according to the Lowry's method (Sigma Aldrich, Total protein kit (TP0300-1KT, USA). All the data were presented as the mean seven standard deviation $(S D)$ results based on per mg of protein.

SOD measurement. Cayman's SOD Assay Kit was used for this measurement. It utilizes a tetrazolium salt for detection of superoxide radicals generated by xanthine oxidase and hypoxanthine. One unit of SOD is defined as the amount of enzyme needed to exhibit $50 \%$ dismutation of the superoxide radical. The assay measures all three types of SOD $(\mathrm{Cu} / \mathrm{Zn}, \mathrm{Mn}$, and Fe SOD). There are two total SOD activity, such as cytosolic and mitochondrial. To separate the two enzymes, supernatant was centrifuged at $10.000 \mathrm{~g}$ for $15 \mathrm{mins}$. at $4{ }^{\circ} \mathrm{C}$. Samples were assayed in the absence of xanthine oxidase to generate a sample background using Elisa reader at $440 \mathrm{~nm}$ of absorbance.

Total GSH measurement. The OxiSelect ${ }^{\mathrm{TM}}$ Total Glutathione Assay Kit was performed for the determination of total GSH. This approach is a quantitative assay for measuring the total GSH content within a sample glutathione/glutathione reductase reduces oxidized glutathione (GSH/GSSG). Briefly, GSSG to reduced GSH in the presence of nicotinamide adenine dinucleotide phosphate (NADPH). Subsequently, the chromogen reacts with the thiol group of GSH to produce a coloured compound that absorbs at $405 \mathrm{~nm}$. The total GSH content in unknown samples is determined by comparison with the predetermined GSH standard curve. The rate of chromophore production is proportional to the concentration of GSH within the sample. Metaphosphoric acid is provided to remove interfering proteins or enzymes from samples.

MDA measurement. The Thiobarbituric Acid Reactive Substances (TBARS) Assay Kit was used for the direct quantitative measurement of MDA. The MDA containing samples or MDA standards are first reacted with the thiobarbituric acid (TBA) at $95{ }^{\circ} \mathrm{C}$. After a brief incubation, the samples and standards were read fluorometrically. The MDA content in samples was determined by comparison with the predetermined MDA standard curve.

\section{Statistical Analysis}

Data was tested for normality with the Shapiro-Wilk test $(p>0.05)$. Analysis of variance (ANOVA) was used for comparisons between groups. Following variance analyses, least significant difference (LSD) multiple comparison test was employed in order to detect which measurement results caused the differences. 
Significance was accepted for values of $p<0.05$ with a $95 \%$ confidence interval.

\section{Results}

Comparison of oxidative stress parameters (SOD, GSH, and MDA) showed in Table 1. When SOD levels were examined, the difference between 15 and 30 mins. exercise groups were statistically significant different from that between other groups $(p<0.05)$. When GSH levels examined, the difference between 30 and 60 mins. groups were statistically different from that between other groups $(p<0.05)$. When MDA levels examined, all exercise groups being compared with the control group had statistically significant differences $(p<0.05)$.

Table 1

Comparison of Different Swimming Exercises on SOD, GSH, MDA Parameters on Cerebellum Tissue

\begin{tabular}{|c|c|c|c|c|}
\hline Groups & $N$ & $\begin{array}{l}\text { SOD } \\
\text { (U/mg protein) }\end{array}$ & $\begin{array}{l}\text { GSH } \\
\text { (nmol/mg protein) }\end{array}$ & $\begin{array}{l}\text { MDA } \\
\text { (nmol/mg protein) }\end{array}$ \\
\hline Control & 8 & $8.36 \pm 1.80 \mathrm{~b}$ & $0.64 \pm 0.19 b$ & $0.15 \pm 0.04 b$ \\
\hline $\begin{array}{l}\text { Short-term exercise } \\
\text { (15 mins.) }\end{array}$ & 8 & $10.53 \pm 2.16 \mathrm{a}$ & $0.79 \pm 0.25 b$ & $0.19 \pm 0.03 \mathrm{a}$ \\
\hline $\begin{array}{l}\text { Moderate-term exercise } \\
(30 \text { mins.) }\end{array}$ & 8 & $11.50 \pm 3.89 \mathrm{a}$ & $1.59 \pm 0.20 \mathrm{a}$ & $0.20 \pm 0.03 \mathrm{a}$ \\
\hline $\begin{array}{l}\text { Long-term exercise } \\
\text { (60 mins.) }\end{array}$ & 8 & $8.30 \pm 1.22 b$ & $1.18 \pm 0.10 \mathrm{a}$ & $0.20 \pm 0.02 \mathrm{a}$ \\
\hline
\end{tabular}

Note. $p<0.05$; ab: Represents the differences among the groups.

\section{Discussion}

ROS occurring in tissue and free radicals can damage biologically important materials, such as DNA protein, carbohydrates, and lipids. As free radicals can come from outside the body, they may also occur as a natural result of the human metabolism. Different natural defense systems in the body in response to damage of ROS keep free radicals under control. These systems are complementary to each other, since they act on different cells and different free radicals (Diplock, 1998).

In the literature, there are studies that showed the different effects on the antioxidant defense system markers (SOD, GSH, and MDA) of exercise (Clarkson \& Thompson, 2000; Kakarla, Vadluri, \& Reddy, 2005; Finaud, Lac, \& Filaire, 2006). In the research that studied the effects of exercise by separating brain into four parts, Rybak, Somani, and Ravi (1995) identified that the antioxidant markers of the experimental group comparing to the antioxidant markers of the control group were higher for each section. Purkinje cells of the cerebellum indicates development of DNA damage that begins at middle age and lasts for whole life. Even more important is that the degeneration and degree in loss of function are managed by lifelong exercise (Cui, Hofer, Rani, Leeuwenburgh, \& Foster, 2009). In this context, this study was designed to examine the acute effect on oxidative stress parameters in the cerebellum tissue of different swimming exercises.

In present study, in the SOD short-term, moderate-term, and long-term exercise group compared with the control group were examined and moderate and short time exercise produced higher SOD values compared to long-term exercise group $(p<0.05)$. Even in the absence of disease, the skeletal muscle itself produces ROS including superoxide anions (Reid et al., 1992; Kolbeck et al., 1997). The SOD value was increased with exercise, but longer exercise period of antioxidant defense system reduced lipid peroxidation and also displayed sufficient capability to cope with the increase in free radicals. The superoxide dismutase (SOD) and catalytic function have been investigated since 1969. Fang, Yang, and Wu (2002) showed that SOD levels of repeated 
sprint exercises made by the subjects had been found to have no significant differences in terms of statistics. However, Ji (1999) stated that there were studies reporting that acute exercise caused an increase in SOD levels in tissues and red blood cells of the various organs (liver, heart, and skeletal muscle).

GSH is also a major component of the cellular antioxidant systems (Fang, Yang, \& Wu, 2002). GSH consisting of glutamic acid, glycine, and cysteine is a tripeptide having more intracellular concentration. GSH, which is important for reducing agent and an important antioxidant, protects cells from the harmful effect of endogenous and exogenous origin oxidant by maintaining balance of the cell oxido-reduction (Comporti, 1987). In response to an increase in free radicals that occur in the cells, GSH oxidizes GSSG (Clarkson \& Thompson, 2000). In the present study, the differences between the GSH levels in rats' cerebellar tissue were examined; moderate and long-term exercise caused higher GSH levels compared to control and short-term exercise groups $(p<0.05)$. Even though cerebellar tissue GSH levels increased statistically in short and moderate-term exercise in rats, numerical decline in GSH levels was found when exercise duration was increased. Gohil, Viguie, Stanley, Brooks, and Packer (1998) found that long-term submaximal exercise may lead to a decrease in GSH levels. Laires et al. (1993) and Viguie et al. (1993) demonstrated similar results. Marin, Hänninen, Müller, and Klinger (1989) reported that 30 mins. treadmill exercise displayed no change of GSH levels. However, Ohno et al. (1986) and Evelo, Palmen, Artur, and Janssen (1992) reported erythrocyte glutathione reductase activity increased after exercise.

MDA is one of the substances that occurs as a result of the lipid peroxidation. It is used as an indicator of oxidative stress. MDA is a final product of lipid peroxidation and is used to show the level of oxidative damage (Fink, 2007). In the present study, the cerebellum tissue MDA was examined, and there were statistically meaningful differences in all exercise groups compared to the control group $(p<0.05)$. This situation makes us consider that the size of the rate of degeneration, which occurs in the cerebellum, may extend the duration of regeneration. Gul et al. (2001) found that MDA levels increased in 90 minutes swimming exercise in rats. Marzatico, Pansarasa, Bertorelli, Somenzini, and Della (1997) detected that MDA increased in sprint and half marathoners, while Sahlin, Ekberg, and Cizinsky (1991) detected the same in acute exercises. Toskulkao and Glinsuko (1996) had a training for 60 mins. corresponding to $70 \%$ of heart rate perform in sedentary individuals with the cycle ergometer, and detected that plasma MDA levels increased five minutes after the exercise and remained high until the 48th hour. However, Alessio et al. (2000) determined that MDA levels did not change in the aerobic exhaustion exercise, while Leaf, Kleinman, Hamilton, and Barstow (1997) determined no change in MDA levels before and after exercise in the maximal exercise.

It can be considered that these different results might be the result of different intensities, duration of exercises, and/or the sample groups. Recently, researchers have begun to investigate the effects of antioxidant system markers in different tissues of different exercise durations (short-term, moderate-term, and long-term) rather than a general exercise (Han, Cho, \& Young, 2011; Kim \& Choi, 2011; Ashrafi \& Roshan, 2012). Prior studies detected exercises performed regularly at a specified intensity increased the anti-oxidant capacity (Leaf, Kleinman, Hamilton, \& Barstow, 1997; Schröder, Navarro, Tramullas, Mora, \& Galiano, 2000). The study identified that the moderate-term exercise group had the highest level of the cerebellum antioxidant markers in the tissue.

\section{Conclusions}

It can be concluded that in acute exercises, a moderate-term exercise enhances the adaption capability by 
increasing the level of oxidative stress parameters and this may reduce lipid peroxidation levels. It was suggested that elevated lipid peroxidation in peripheral blood may indicate a systemic elevation of oxidative stress and a failure of the antioxidant system to sufficiently neutralize the increased production of reactive oxygen species (Sultana, Perluigi, \& Allan, 2013).

\section{References}

Alessio, H. M., Hagerman, A. E., Fulkerson, B. K., Ambrose, J., Rice, R. E., \& Wiley, R. L. (2000). Generation of reactive oxygen species after exhaustive aerobic and isometric exercise. Medcine and Science in Sports and Exercise, 32(9), 1576.

Andreazza, A. C. (2012). Combining redox-proteomics and epigenomics to explain the involvement of oxidative stress in psychiatric disorders. Mol Biosyst, 8(10), 2503-2512.

Ashrafi, J., \& Roshan, V. D. (2012). Is short-term exercise a therapeutic tool for improvement of cardioprotection against DOX-induced cardiotoxicity? An experimental controlled protocol in rats. Asian Pacific Journal of Cancer Prevention, 13(8), 4025-4030.

Balu, M., Sangeetha, P., Murali, G., \& Panneerselvam, C. (2006). Modulatory role of grape seed extract on age-related oxidative DNA damage in central nervous system of rats. Brain Research Bulletin, 68(6), 469-473.

Bando, N., Wakamatsu, S., \& Terao, J. (2007). Effect of an excessive intake of quercetin on the vitamin E level and an tioxidative enzyme activities of mouse liver under paraquat-induced oxidative stress. Biosci Biotechnol Biochem, 71(10), $2569-2572$.

Brand, M. D., Affourtit, C., Esteves, T. C., Green, K., Lambert, A. J., Miwa, S. et al. (2004). Mitochondrial superoxide: Production, biological effects, and activation of uncouplingproteins. Free Radic Biological Medcine, 37(6), 755-767.

Clarkson, P. M., \& Thompson, H. S. (2000). Antioxidants: What role do they play in physical activity and health? The American Journal of Clinical Nutrition, 72(2), 637-646.

Close, G. L., Ashton, T., McArdle, A., \& Jackson, M. J. (2005). Microdialysis studies of extracellular reactive oxygen species. Free Radical Biology \& Medicine, 39(11), 1460-1467.

Comporti, M. (1987). Glutathione depleting agents and lipid peroxidation. Chemistry and Physics of Lipids, 45(2), 143-169.

Cui, L., Hofer, T., Rani, A., Leeuwenburgh, C., \& Foster, T. C. (2009). Comparison of lifelong and late life exercise on oxidative stress in the cerebellum. Neurobiology of Aging, 30(6), 903-909.

Devi, L., Badanavalu, M. P., Domenico, F. G., Narayan, G. A., \& Hindupur, K. A., (2006). Accumulation of amyloid precursor protein in the mitochondrial import channels of human alzheimer's disease brain is associated with mitochondrial dysfunction. The Journal of Neuroscience, 26(35), 9057-9068.

Diplock, A. T. (1998). Defence against reactive oxygen species. Free Radical Research, 29(6), 463-467.

Duruturk, N., Tonga, E., Karatas, M., \& Doganozu, E. (2015). Activity performance problems of patients with cardiac diseases and their impact on quality of life. Journal of Physical Therapy Science, 27(7), 2023.

Evelo, C. T. A., Palmen, N. G. M., Artur, Y., \& Janssen, G. M. E. (1992). Changes in blood glutathione concentrations, and in erythrocyte glutathione reductase and glutathione-S-transferase activity after running training and after participation in contests. European Journal of Applied Physiology and Occupational Physiology, 64(4), 354-358.

Fang, Y. Z., Yang, S., \& Wu, G. (2002). Free radicals, antioxidants, and nutrition. Nutrition, 18(10), 872-879.

Feng, Y. Z., Liu, Y. M., Fratkins, J. D., \& Leblan, M. H. (2005). Grape seed extract suppresses lipid peroxidation and reduces hypoxic ischemic brain injury in neonatal rats. Brain Research Bulletin, 66(2), 120-127.

Ferreira, L. F., \& Reid, M. B. (2008). Muscle-derived ROS and thiol regulation in muscle fatigue. Journal of Applied Physiology, 104(3), 853-860.

Fink, M. P. (2007). Ethyl pyruvate: A novel anti-inflammatory agent. Journal of Internal Medicine, 261(4), 349-362.

Finaud, J., Lac, G., \& Filaire, E. (2006). Oxidative stress. Sports Medicine, 36(4), 327-358.

Gleeson, M., \& Bishop, N. C. (2000). Modification of immune responses to exercise by carbohydrate, glutamine and anti-oxidant supplements. Immunology and Cell Biology, 78(5), 554-561.

Gohil, K., Viguie, C., Stanley, W. C., Brooks, G. A., \& Packer, L. (1998). Blood glutathione oxidation during human exercise. Journal of Applied Physiology, 64(1), 115-119.

Gul, M., Oztasan, N., Taysi, S., Gumustekin, K., Akar, S., \& Bakan, N. (2001). Short-term swimming exercise as an oxidative stress model in rat. Hacettepe Journal of Sport Sciences, 12(4), 26-32.

Han, G., Cho, B., \& Young, M. T. (2011). Endurance exercise reduces oxidative stress in mice. Journal of Physical Therapy Science, 23(4), 539-541. 
Jackson, M. J., Pye, D., \& Palomero, J. (2007). The production of reactive oxygen and nitrogen species by skeletal muscle. Journal of Applied Physiology, 102(4), 1664-1670.

Ji, L. L. (1999). Antioxidants and oxidative stress in exercise. Experimental Biology and Medicine, 222(3), $283-292$.

Kakarla, P., Vadluri, G., \& Reddy, K. S. (2005). Response of hepatic antioxidant system to exercise training in aging female rat. Journal of Experimental Zoology Part A: Comparative Experimental Biology, 303(3), 203-208.

Kaur, C., \& Kapoor, H. C. (2001). Anti-oxidant activity and total phenolic content of some Asian vegetables. International Journal of Food Science and Technology, 37(2), 153-161.

Kim, S., \& Cho, B. (2011). A study of acute maximal workload on oxidative stress response with the obese. Journal of Physical Therapy Science, 23(5), 777-780.

Kolbeck, R. C., She, Z. W., Callahan, L. A., \& Nosek, A. T. M. (1997). Increased superoxide production during fatigue in the perfused rat diaphragm. American Journal of Respiratory and Critical Care Medicine, 156(1), 140-145.

Laires, M. J., Madeira, F., Sergio, J., Colaco, C., Vaz, C., \& Felisberto, G. M. (1993). Preliminary study of the relationship between plasma and erythrocyte magnesium variations and some circulating pro-oxidant and antioxidant indices in a standardized physical effort. Magnesium Research, 6(3), 233-238.

Leaf, D. A., Kleinman, M. T., Hamilton, M., \& Barstow, T. J. (1997). The effect of exercise intensity on lipid peroxidation. Medicine and Science in Sports and Exercise, 29(8), 1036-1039.

Lira, V. A., Benton, C. R., Yan, Z., \& Bonen, A. (2010). PGC-1 $\alpha$ regulation by exercise training and its influences on muscle function and insulin sensitivity. American Journal of Physiology-Endocrinology and Metabolism, 299(2), 145-161.

Marin, E., Hänninen, O., Müller, D., \& Klinger, W. (1989). Influence of acute physical exercise on glutathione and lipid peroxides in blood of rat and man. Acta Physiol Hung, 76(1), 71-76.

McArdle, F., Pattwell, D. M., Vasilaki, A., McArdle, A., \& Jackson, M. J. (2005). Intracellular generation of reactive oxygen species by contracting skeletal muscle cells. Free Radical Biology and Medicine, 39(5), 651-657.

Marzatico, F., Pansarasa, O., Bertorelli, L., Somenzini, L., \& Della, V. G. (1997). Blood free radical antioxidant enzymes and lipid peroxides following long-distance and lactacidemic performances in highly trained aerobic and sprint athletes. The Journal of Sports Medicine and Physical Fitness, 37(4), 235-239.

Mylonas, C., \& Kouretas, D. (1998). Lipid peroxidation and tissue damage. In Vivo (Athens, Greece), 13(3), 295-309.

Nakae, H., \& Tsushima, H. (2014). Effects of home exercise on physical function and activity in home care patients with Parkinson's disease. Journal of Physical Therapy Science, 26(11), 1701-1706.

Ohno, H., Sato, Y., Yamashita, K., Doi, R., Arai, K., Kondo, T., \& Taniguchi, N. (1986). The effect of brief physical exercise on free radical scavenging enzyme systems in human red blood cells. Canadian Journal of Physiology and Pharmacology, 64(9), $1263-1265$.

Pikulski, M., \& Brodbelt, J. S. (2003). Differentiation of flavonoid glycoside isomers by using metal complexation and electrospray 1onization mass spectrometry. Journal of the American Society for Mass Spectrometry, 14(12), 1437-1453.

Prior, R. L., Wu, X., \& Scaich, K. (2005). Standardized methods for the determination antioxidant capacity and phenolics in foods and dieatry supplements. Journal of Agricultural and Food Chemistry, 53(8), 3110-3113.

Reid, M. B., Haack, K. E., Franchek, K. M., Valberg, P. A., Kobzik, L., \& West, M. S. (1992). Reactive oxygen in skeletal muscle. I. Intracellular oxidant kinetics and fatigue in vitro. Journal of Applied Physiology, 73(5), 1797-1804.

Rice-Evans, C. A., Miller, N. J., Bolwell, P. G., Bramley, P. M., \& Pridham, J. B. (1995). The relative activities of plant-derived poliphenolic flavonoids. Free Radical Research, 22(4), 375-383.

Richardson, R. S., Noyszewski, E. A., Kendrick, K. F., Leigh, J. S., \& Wagner, P. D. (1995). Myoglobin O $_{2}$ desaturation during exercise. Evidence of limited $\mathrm{O}_{2}$ transport. Journal of Clinical Investigation, 96(4), 1916.

Rybak, L. P., Somani, S. M., \& Ravi, R. (1995). Effect of exercise training on antioxidant system in brain regions of rat. Pharmacology Biochemistry and Behavior, 50(4), 635-639.

Sahlin, K., Ekberg, K., \& Cizinsky, S. (1991). Changes in plasma hypoxanthine and free radical markers during exercise in man. Acta Physiol Scand, 142(2), 275-281.

Schröder, H., Navarro, E., Tramullas, A., Mora, J., \& Galiano, D. (2000). Nutrition antioxidant status and oxidative stress in professional basketball players: Effects of a three compound antioxidative supplement. International Journal of Sports Medicine, 21(02), 146-150.

Shao, Z. H., Terry, L., Hoek, V., Xie, J., \& Wojcik, K. (2009). Grape seed proanthocyanidins protect cardiomyocytes from ischemia and reperfusion injury via akt-nos signaling. Journal of Cellular Biochemistry, 107(4), 697-705. 
Sultana, R., Perluigi, M., \& Allan, B. D. A. (2013). Lipid peroxidation triggers neurodegeneration: A redox proteomics view into the Alzheimer disease brain. Free Radical Biology and Medicine, 62, 157-169.

Toskulkao, C., \& Glinsukon, T. (1996). Endurance exercise and muscle damage: Relationship to lipid peroxidation and scavenging enzymes in short and long distance runners. Japanese Journal of Physical Fitness and Sports Medicine, 45(1), 63-70.

Viguie, C., Frei, B., Shigenaga, M., Ames, B., Packer, L., \& Brooks, G. (1993). Antioxidant status and indexes of oxidative stress during consecutive days of exercise. Journal of Applied Physiology, 75(2), 566-572.

Von, S., C. (2006). Free-radical-induced DNA damage and its repair. Verlag Berlin Heidelberg New York: Springer.

Zschucke, E., Gaudlitz, K., \& Ströhle, A. (2013). Exercise and physical activity in mental disorders: Clinical and experimental evidence. Journal of Preventive Medicine and Public Health, 46(1), 12-21.

Zuo, L., Pasniciuc, S., Wright, V. P., Merola, A. J., \& Clanton, T. L. (2003). Sources for superoxide release: Lessons from blockade of electron transport, NADPH oxidase, and anion channels in diaphragm. Antioxid Redox Signal, 5(5), 667-675. 


\title{
Possible Explanation for Cancer in Rats due to Cell Phone Radiofrequency Radiation
}

\author{
Bernard J. Feldman \\ University of Missouri-St. Louis, St. Louis, USA
}

\begin{abstract}
Very recently, the National Toxicology Program reported a correlation between exposure to whole body $900 \mathrm{MHz}$ radiofrequency radiation and cancer in the brains and hearts of Sprague Dawley male rats. Assuming that the National Toxicology Program is statistically significant, we propose the following explanation for the results. The neurons around the brain and heart form closed electrical circuits and, following Faraday's Law, $900 \mathrm{MHz}$ radiofrequency radiation induces $900 \mathrm{MHz}$ electrical currents in these neural circuits. In turn, these $900 \mathrm{MHz}$ currents in the neural circuits generate sufficient localized heat in the neural cells to shift the equilibrium concentration of carcinogenic radicals to higher levels, and thus, to higher incidences of cancer. These ideas are then applied to the question of the risk to humans from cell phone radiofrequency radiation.
\end{abstract}

Keywords: cancer, cell phone radiofrequency radiation, rats, mice, Faraday's Law, schwannomas, gliomas, neural circuits

\section{Introduction}

The question whether cell phone radiofrequency radiation causes cancer is of great interest to virtually every student, given the incredible high percentage of students who use cell phones numerous times every day. This paper summarizes the very recent and most conclusive results on this question and then presents a simple theory to explain these results, using only freshman level science. In particular, the only scientific ideas used in the explanation are Faraday's Law and Ohm's Law from physics, the law of mass action from chemistry, and physiological facts from biology. This material would be appropriate for most high school, college, and university introductory science classes. There is also a brief discussion of the risk to humans from cell phone radiofrequency radiation.

Very recently, the National Toxicology Program (Wyde et al., 2016) reported a correlation between exposure to whole body radiofrequency radiation and cancer in Sprague Dawley rats. The experiment consisted of irradiating Sprague Dawley rats and B6C3F1 mice with $900 \mathrm{MHz}$ radiation with four different intensity exposures: $0 \mathrm{~W} / \mathrm{kg}, 1.5 \mathrm{~W} / \mathrm{kg}, 3 \mathrm{~W} / \mathrm{kg}$, and $6 \mathrm{~W} / \mathrm{kg}$. The frequency of $900 \mathrm{MHz}$ is typical for use in cell phones and other wireless devices. The exposures were 10 mins. on and 10 mins. off for 18 hours a day, resulting in a total exposure of nine hours daily. The animals were exposed daily from in utero until two years of age. The animals were monitored so that exposure was at a low non-thermal or non-heating level. Groups of 90 animals were used for each species, sex, and intensity.

They reported the following results:

Bernard J. Feldman, Dr., professor, Department of Physics and Astronomy, University of Missouri-St. Louis. 
1. Excess cancers were found only in male rats but not in female rats, male mice, or female mice;

2. Only brain cancers (gliomas and brain lesions) and heart cancers (schwannomas) were found. Schwannomas are cancers of the neural cell sheaths;

3. The incidence of cancer in male rats increased as the $900 \mathrm{MHz}$ radiofrequency intensity increased from 0 to $6 \mathrm{~W} / \mathrm{kg}$. In particular, no cancers were found in any animal that was not exposed to radiofrequency radiation $(0 \mathrm{~W} / \mathrm{kg})$;

4. Even at the highest radiofrequency power, $6 \mathrm{~W} / \mathrm{kg}$, this power was insufficient to increase the rats' average body temperature by more than one degree centigrade;

5. The rats exposed to radiofrequency radiation lived longer than those rats that were not exposed;

6. Analysis of bioassays showed that "male rats are more sensitive to chemical carcinogenesis compared to female rats;"

7. A small minority of the reviewers of this study questioned the statistical significance of these results. One of the authors also mentioned that previous studies by other groups had found similar brain and heart excess cancers in humans due to radiofrequency radiation (Melnick, 2016).

\section{Previous Work}

Theoretical understanding of the interaction between animals and electromagnetic radiation has a long and complicated history. Physicists, in general, have been very skeptical of any connection between any non-ionizing radiation and cancer. The classic paper by Adair (1992) on weak extremely-low-frequency $(60 \mathrm{~Hz})$ electromagnetic fields concluded that "such interactions are too weak to have a significant effect on human biology at the cell level." Adair applied Faraday's Law to a cell radiated with weak $60 \mathrm{~Hz}$ electromagnetic fields and concluded that the induced electric field is small compared to thermal noise induced electric fields. Even this author expressed skepticism about cell phone radiation $(900 \mathrm{MHz})$ causing cancer by using an analogy with Einstein's theory of the photoelectric effect - the $900 \mathrm{MHz}$ photon energies are about a million times less than the energy needed to break chemical bonds (Feldman, 2014). Recently, Barnes and Greenebaum (2016) proposed that weak static and high frequency magnetic fields could change the recombination rate of radical pairs, and thus, change the concentration of carcinogenic radicals like $\mathrm{O}_{2}^{-}$in cells. Panagopoulos, Johansson, and Carlo (2015) suggested that high frequency electric fields exert electrostatic forces on the cell membrane, disrupting the functioning of the ion channels.

\section{Theoretical Model}

Assuming that the National Toxicology Program is statistically significant, the following explanation for the results is proposed. The neurons around the brain and heart form closed electrical circuits and, following Faraday's Law, $900 \mathrm{MHz}$ radiofrequency radiation induces $900 \mathrm{MHz}$ electrical currents in these neural circuits. Given that these neural circuits could be one neuron in width and neuron axons are about one micrometer in diameter, these $900 \mathrm{MHz}$ currents in the neural circuits could generate sufficient localized heat in the neural cells to significantly raise the temperature of the neural and neighboring cells and shift the equilibrium concentration of carcinogenic radicals in these cells to higher levels and thus, to higher incidences of cancer.

Consider a neural circuit on the surface of the brain or the heart in the shape of a circle of radius $r$. From Faraday's Law, the induced voltage, $V$, in the neural circuit is equal to minus the time $(t)$ derivative of the 
magnetic flux crossing the closed circuit. Assuming that the radiofrequency magnetic field is $B=\mathrm{B}_{0} \cos (\omega t)$, where $\mathrm{B}_{0}$ is a constant and $\omega / 2 \pi=900 \mathrm{MHz}$, then $V=\omega \mathrm{B}_{0} \sin (\omega t) \pi r^{2}$ and is proportional to $\mathrm{B}_{0}, r^{2}$, and $\omega$. The resistance of the neural circuit, $R$, is proportional to its circumference, and thus, proportional to $r$, since second (power) in the neural cells, $P=V^{2} / R$, and is proportional to $\mathrm{B}_{0}{ }^{2}, \omega^{2}$, and $r^{3}$, and the heat generated per second per unit length of the neural circuit is proportional to $\mathrm{B}_{0}{ }^{2}, \omega^{2}$, and $r^{2}$.

Now question arises - How could this excess localized heat cause cancer? Again, let us consider a simple model consisting of carcinogenic radicals like oxidants, $\mathrm{O}$, and antioxidants that scavenge these radicals, A. Inside cells, chemical reactions occur that convert food into useful chemicals, heat, and muscular motion. Carcinogenic radicals are created as waste products. In order for the animal to protect itself from these carcinogenic radicals, the cells create antioxidants. The antioxidants bind to the carcinogenic radicals forming harmless molecules, OA, which then diffuse to nearby veins and are removed from the body via the kidneys and urinary system. The concentrations of $\mathrm{O}$ and $\mathrm{A}$ are in approximate equilibrium with OA, namely, the cell's rate of production of $\mathrm{O}$ equals the cell's rate of production of $\mathrm{A}$, which in turn, equals the rate of removal of OA from the cell. One can write down the following chemical reaction:

$$
\mathrm{O}+\mathrm{A}=\mathrm{OA} \text {. }
$$

From the law of mass action, at equilibrium, the concentrations of $\mathrm{O}$ ([o]), A ([a]), and OA ([oa]), are related to an equilibrium constant $\mathrm{K}$ that depends of temperature.

$$
\begin{gathered}
{[\mathrm{oa}] /[\mathrm{o}][\mathrm{a}]=\mathrm{K}(\mathrm{T})} \\
\mathrm{K}(\mathrm{T})=\mathrm{C} \exp (-\mathrm{G} / \mathrm{RT})
\end{gathered}
$$

Here, $\mathrm{C}$ is a constant, $\mathrm{T}$ is the temperature in Kelvin, $\mathrm{G}$ is the Gibbs free energy of the chemical reaction, and $\mathrm{R}$ is the gas constant. $G$ is negative for exothermic reactions. Notice as the temperature goes up, $K(T)$ goes down, and [o] and [a] go up. An increase in [o] is believed to be connected with an increase in the cancer rate.

An alternative possibility is that the increased temperature denatures antioxidants (they loses their structure and thus their ability to function), leaving higher concentrations of carcinogenic radicals. In humans, proteins start to denature when the body temperature is above $42{ }^{\circ} \mathrm{C}$, causing death; this temperature is only $5{ }^{\circ} \mathrm{C}$ above the human body temperature of $37^{\circ} \mathrm{C}$.

\section{Comparison Between Model and Experiments}

This model is reasonably consistent with the National Toxicology Program's experimental observations. The cancers are found near neurons and in large organs that are surrounded by or largely consist of neural cells, like the brain and the heart, but not found in small organs, like the thyroid, prostate, or the kidney or in large organs not surrounded by or consisting of neural cells, like the pancreas, lung, or the liver. The incidence of cancer increased with the radiofrequency intensity, which is proportional to $\mathrm{B}_{\mathrm{o}}{ }^{2}$. Even though the rats' average body temperature does not increase significantly, there could be significant localized heating of these neural circuits undetected by the National Toxicology Program. Given that male Sprague Dawley rats are on average about $60 \%$ heavier (and thus about $60 \%$ larger) than female Sprague Dawley rats at 15 weeks of age, the model does predict a higher incidence of cancer in male rats than female rats, but the increased sensitivity of male rats to chemical carcinogenesis probably plays a much bigger role in this difference.

This model is also consistent with the observation that no cancers were found in mice. Since mice are about a factor of three smaller in size than the Sprague Dawley rats, our theory predicts that the incidence of cancer should be reduced by a factor of 9 . Given that the incidence of cancer in male rats was barely 
statistically significant, a factor of 9 would predict no cancer observed in male mice. This observation of no cancer in male mice strongly argues against any cancer mechanism that is at the cellular or molecular level, like those suggested by Barnes and Greenebaum (2016) and Panagopoulos, Johansson, and Carlo (2015). Given that nerve cells are about the same size in mice and rats and the genetics and biology of mice and rats are extremely similar, a cellular or molecular theory of cancer would predict cancer in male mice, if there is cancer in male rats. Finally, this model is consistent with a recent article by Burlaka et al. (2013), reporting the overproduction of free radicals in quail embryonal cells exposed to cell phone radiation.

Finally, the National Toxicology Report did comment on the observation that irradiated rats lived longer than non-irradiated rats (Wyde et al., 2016). They suggested that it is related to the observation that calorie-restricted animals live longer on average. The radiofrequency radiation that is absorbed by rats generates heat throughout their bodies, thus leading to less consumption of food and less production of carcinogenic radicals.

\section{Model Predictions}

This model makes some predictions. Given that the male Sprague Dawley rats at age 15 weeks range in weight (and thus size) from 320-460 grams, this model predicts that the larger male rats should have a higher incidence of cancer than the smaller male rats. This model also predicts that the incidence of cancer should increase as the square of the radio wave frequency, assuming that the resistance of the neural circuit does not change with frequency. It is clear that this mechanism is not relevant to $60 \mathrm{~Hz}$ electromagnetic fields, given that $60 \mathrm{~Hz}$ is so much smaller than $900 \mathrm{MHz}$.

Finally, how are these ideas connected with the relationship between cell phone radiation and cancer in humans? At first glance, one might conclude that the incidence of cancer due to cell phone radiation should be much greater in humans than in rats, because our hearts and brains are so much bigger. Let me caution against such simple logic for the following reasons:

1. Rats are not perfect analogues to humans. There are diseases found in rats that are not found in humans and visa versa;

2. The rats were exposed to radiation nine hours a day from utero to the time they were killed, while the exposure in humans is much less;

3. The radiation actually increased the lives of the rats. If the same is true in humans, many human autopsies would not be looking for these types of cancers.

The question of cancer in humans due to radiofrequency radiation must ultimately be determined by epidemiologic studies on humans. A very recent publication by Wojcik (2016) on a meta-analysis of many different human epidemiologic studies reported that the risk for glioma increased by a factor of 1.9 for cell phone users; it also mentioned the French Cerent collaborative case-control study that showed the risk for glioma increased by a factor of 2.89 for heavy cell phone users. Clearly, our students should be made aware of this risk and hopefully, the inclusion of this material in their science classes will further that awareness.

\section{References}

Adair, R. K. (1992). Constraints on biological effects of weak extremely-low-frequency electromagnetic fields. Physical Review A, 43, 1039-1048.

Barnes, F., \& Greenebaum, B. (2016). Some effects of weak magnetic fields on biological systems. IEEE Power Electronics Magazine, March, 60. 
Burlaka, A., Tsybulin, O., Sidorik, E., Lukin, S., Polishuk, V., Tsehmistrenko, S., \& Yakymenko, I. (2013). Overproduction of free radical species in embryonal cells exposed to low intensity radiofrequency radiation. Experimental Oncology, 35, 219-225.

Feldman, B. (2014). Physics déjà vu. The Physics Teacher, 52, 391.

Melnick, R. (2016). Cell phone radiation boosts cancer rates in animals; $\$ 25$ million NTP study finds brain tumors. Microwave News. Retrieved May 25, 2016, from http://microwavenews.com/news-center/ntp-cancer-results

Panagopoulos, D., Johansson, O., \& Carlo, G. (2015). Polarization: A key difference between man-made and natural electromagnetic fields, in regard to biological activity. Retrieved October 12, 2015, from http://www.Nature.com/Scientific Reports 5:14914

Wojcik, D. (2016). Primary brain tumors and mobile phone usage. Cancer Epidemiology, 44, 123-124.

Wyde, M., Cesta, M., Blystone, C., Elmore, S., Foster, P., ... \& Bucher, J. (2016). Report of partial findings from the National Toxicology Program carcinogenesis studies of cell phone radiofrequency radiation in Hsd: Sprague Dawley SD rats (whole body exposures). Retrieved May 26, 2016, from http://biorxiv.org/content/early/2016/05/26/055699.full.pdf and https://ecfsapi.fcc.gov/file/10011773529766/EHTrustNTP.pdf 


\title{
Between Sociological Theory and Professional Practice: Integration Experiences in University Traineeship Programmes
}

\author{
Marco Accorinti \\ Institute for Research on Population and Social Policies of Rome (IRPPS), Rome, Italy
}

\begin{abstract}
This paper presents a reflection on the integration of sociology and social work into a degree programme offered by the Faculty of Sociology of Sapienza University of Rome. In particular, it explores the experience of designing the course (in accordance with the provisions contained in Ministerial Decree No. 509 of 3 November 1999 to Ministerial Decree No. 270 of 22 October 2004) and the training pathway for both social workers and sociologists (and other social policy experts). The underlying vision is a perspective of social work that emphasises many sources of knowledge and the formalization of in-field experience.
\end{abstract}

Keywords: education, university, social work

\section{Introduction}

In Italy, university studies are structured in accordance with the provisions contained in the Decree of the Ministry of Education, University and Research No. 270 of 22 October 2004, which provides for three cycles (or levels) of studies. The first two cycles cover the entire university pathway, with a three-year first-cycle (or Bachelor's) degree programme and a two-year second-cycle (or Master's) degree programme (Laurea Magistrale). The third cycle is related to higher education.

In response to the new regulatory requirements, Sapienza University restructured its educational offering concerning social work and changed the set up of the course that it had put in place under the previous university system provided for in Ministerial Decree No. 509 of 3 November 1999. In particular, Sapienza University has been offering two first-cycle and one second-cycle (specialisation) degree programmes, initially in the Faculty of Sociology and now in the Department of Social and Economic Sciences.

This text does not intend to present technicalities and bureaucratic procedures, nor the formal complexity of the structure of a degree programme in social work. The idea is to reason on the logic and processes underlying the regulations of the Master's degree, which have been amended three times over the course of a few years. An attempt is made to outline the development of the curriculum of the Master's degree in social work, with a special focus on the traineeship programme and its integration with sociological and social work theory.

In the practice of Sapienza University, the typical implications of social workers' professional activities became increasingly important in the curriculum of the Master's degree in social work. Traineeship was helpful for both understanding organisational aspects (social research) and providing actual training. The knowledge

Marco Accorinti, Italian National Research Council (CNR) researcher, Institute for Research on Population and Social Policies of Rome (IRPPS). 
and the organisational and innovational processes of social services, placed in their specific contexts in time and space, were investigated and then studied by students. With this prospect, teachers (as well as students) with different cultural backgrounds (i.e., social work and sociology) helped to theorise social practice, based on the understanding and the study of the organisations and systems involved in social work. In designing teaching and traineeship work, the theoretical and practical implications of representing the organisational knowledge of social work were taken into account. Experts in both social research and social work interacted regularly to define the curriculum, classroom activities, the traineeship programme, final tests, etc.. The analysis of 10 years of experience is intended to show how the educational activity of the traineeship programme was organised, which integrated knowledge from different areas.

\section{The Transition to a New System}

\section{Previous Academic System}

With the change of the curriculum under Ministerial Decree 270/2004, the new course of the Master's degree has been based on the previous academic system and experience since the academic year 2010/2011, even though additional legal requirements were introduced. Among others, the 120 university credits (CFUs) can no longer be obtained by taking exams that are supplementary to the social work curriculum, and a traineeship programme is mandatory for all students.

The conceptual framework of the programme was based on the knowledge of a set of elements that can be summarised in the following eight points:

(a) methodological principles and techniques for analysing social phenomena;

(b) the functioning of European welfare models (including the Italian one) in terms of composition, aims, action strategies, main stakeholders, and relevant agencies;

(c) rules and directives on social policies and services issued at a European, domestic, regional, and local level;

(d) the functioning of central and local governments and public services;

(e) theories and procedures for assessing policies and social services;

(f) forms of interaction among public, private, and third sector organisations;

(g) partnership mechanisms (outsourcing, accreditation, etc.) at a local level;

(h) consultation and participation of citizens, including in associative forms.

Most students were neither experienced social workers who wanted to keep themselves abreast of current developments, nor sociologists with an inclination towards social aid. They were either students from the relevant three-year degree programme (hence, with little experience of social work, but the traineeship hours) or students from other degree programmes, who could directly access the course under the new regulations, without any additional academic requirements (obblighi formativi). During the initial years, students who were not social workers were advised to take courses related to the profession of social worker (these courses had to be paid for and included in the students' overall study paln. In practice, there was a clear-cut differentiation between social worker students and non-social worker students, within a course that was originally designed as a specialisation in social work. Moreover, ministerial directions did not provide for the possibility to define "additional academic requirements" in the students' study plan. Hence, the programme had to be designed as a single course with 120 CFUs. 


\section{Renew Academic System}

However, in order to continue offering education to non-social-worker students, as the teaching staff considered this to be a positive experience, the Dean of the Faculty tried to pursue two avenues. The idea was to keep the vocation of the course, that is to say, vocational training in a large area of social work, with some possible differences in terms of goals and carrier opportunities. To this end, the Dean had tried to intervene in the very complex university framework and had initially designed the first year as common to all students, with two options for the second year: Curriculum A-Professional Coordination of Social Services (specifically for students who were already social workers); and Curriculum B-Analysis and Assessment of Social Policies and Services. The two curricula were intended for people with two different backgrounds entering (but also leaving) the programme. They differed in terms of educational approach more than in terms of the number or type of exams to be taken. For one of the curricula, the 120 CFUs of the programme included 10 CFUs under the heading "other educational activities," consisting of the "in-depth work in professional areas" of social work, in accordance with what was specified in the first project authorised by the university. The choice was to design an education activity that could be about practical experience and in-depth analysis, while waiting for national decisions to be taken in consultation with the professional association.

However, since it was not possible to have different curricula, the Dean of the faculty decided to introduce more social work courses, focusing on traineeship and using the skills of expert social workers and sociologists. Experts in assessment, research methodology, and policy analysis were directly involved in research on social services. Moreover, professionals with expertise in social services were engaged to teach in workshops about specific professional practice.

Students were required to attend at least $70 \%$ of workshop hours. Workshops included a final test, with each student writing and discussing an original paper, and it was to be used also for the final thesis at the end of the degree programme. To help students, especially those who had a job, workshops were timetabled as four-hour classes on Fridays and Saturdays. Each workshop consisted of seven classes, for a total of 32 hours of work (including classroom activity and individual work).

The programme offered six workshops in the first year and five in the second year. Students had to choose three of these workshops, plus one for their traineeship. All students had to take a compulsory module, Essential Assistance Levels (LIVEAS), whereas they could choose the other modules, which were offered in one of the two academic semesters. For the first experimental year, the traineeship consisted of 150 hours (certified), including some time (approximately 20 hours) for planning activities. The traineeship projects were developed by students themselves, agreed with the supervisor (a social worker) and approved by the traineeships coordinator. Furthermore, the traineeships did not provide for contacts with the users of services, as they were not about social assistance.

Besides LIVEAS workshops, the other workshops were the following: Support for Accessing Care Services (Social Secretariat); Complex Interventions with Children; Social and Occupational Integration; The Organisational Relation: Professional Culture and Practices; and Complex Interventions with Immigrants. The workshops were entrusted to six teachers: Three experienced social workers (two of them had responsibilities in organising social services) and three experts in social policies and interventions. To some extent, the expertise of these teachers helped us understand the quality and the interdisciplinary character of the programme. Moreover, the importance of experience-based learning was always stressed during training in the classroom, 
often with the participation of "testimonials" (coordinators, managers, and key figures in the system of social services) or professionals working in the area of social services. Finally, workshops were also designed in an integrated manner. They included traineeship activities and the preparation of a thesis. The aim was to give students an opportunity to do both theoretical and methodological work, that is to say, to learn social work theories and acquire the skills needed for interpreting the complex needs of people, managing services, and assessing the quality of such services. The workshops held by social workers gave students who were already social workers the possibility of doing second-level traineeship in specific areas. The workshops were intended to be an opportunity to gain an understanding of and explore social work interventions in some sectors. It was thought, in fact, that a learning approach based on the integration between social work theory and practice would make it possible to tackle the topics of the organisation of social services and policy and intervention assessment from a different but complementary perspective. The conviction was that social work theory should be built on specific research and investigation of social work practice from an interdisciplinary perspective.

The change, made necessary by the new legal provisions, promoted the introduction of a "specialistic" traineeship, valid for all students. As this traineeship did not consist of direct work with users, it provided a broader and integrated reading of social work, which included research activities, assessment, a systemic approach, and analysis and project development. Students compared notes with the persons in charge of services, decision makers, other professionals, researchers, and assessors. This integrated work was guided by a supervisor who had to have organisational duties in social services, which guaranteed a high-level traineeship. In this way, students coming from the Faculty of Sociology were expected to undertake practical research, for instance, on the organisation and system-wide implementation of a social secretariat, while social worker students could analyse the theoretical implications of social work when devising a social plan at a local level.

Then, the faculty decided to change the educational offering of traineeships in the Master's degree programme. However, the experience acquired seems to be an interesting case study of educational integration, a topic on which the following considerations are proposed.

\section{Is It Possible to Integrate Professional Skills in Social Work into a University Curriculum?}

To consider what type of knowledge is (or should be) taught and how it could be useful for professional social work means acknowledging the need to adjust and update such knowledge with the changes introduced in the welfare system by the "knowledge-based society" (as it is usually defined). In fact, authors, such as Wenger (1998), rightly argued that a social learning system was built by professionals, who worked as the "social containers" of the skills needed in social work. Wenger (1998) maintained that communities of professionals could grow by combining expertise and personal experience in a context of common practice. Hence, the interaction between professional expertise and scientific knowledge can create the best opportunities to enhance learning and innovation.

The experience of designing the Master's degree programme in social work offered by the Faculty of Sociology of Sapienza University of Rome, outlined in the previous section, suggests that combining professional expertise with scientific knowledge in the area of social services is feasible. Such an approach should focus on the development of social policies in the country, and most importantly, on the networks of relations that are intrinsic to work in the social sector.

Indeed, both practical experience and university reforms led to the design of a Master's degree programme that was intended to train specialised social workers, but also to educate future professionals who would have to 
tackle social work-related problems against a specific social and local background, while reflecting on organisational and professional issues. The designing of this course was an opportunity for defining the profile of a "manager" who could coordinate research and screening programmes in given catchment areas, monitor and assess the policy impacts of national and sub-national plans on the integrated organisation of services, and design a system of social intervention at a local level. In the educational offering, a key role was played by the traineeship experience within local assistance authorities, which was one of the logical links between the two cycles of the degree programmes. This traineeship was a way to involve students in issues related to organisation, management, assessment, research, and staff within the context of social work in a pragmatic and controlled manner.

If, as maintained by Reboul (1996), professional expertise was a complex level of learning and merging knowledge (hence theory, "knowing that...”) and skill levels (hence practice, "know-how”), teaching social work skills essentially would translate into training experts who should be able to address social work-related issues, as well as raise, construct, and solve a problem by correctly referring its context (Fabre, 1999). Hence, on the one hand, lecturers tried to educate the community of future professionals by helping them to reflect on shared rules, common resources, the language used, and their own routines. On the other hand, they focussed on the development processes that were necessary to increase professional skills. This implied that students were offered seminars and research experiences, in particular research aimed at assessing social work. Students were required to pursue their theoretical studies not by simply taking individual courses on any given subject, but by focussing on broader scientific approaches. Finally, they had to submit final dissertations that were aimed at understanding the complexities of social work and how to be a professional in social work.

The analysis of the academic programme conducted so far might be affected by a personal involvement. However, it can be argued that the intended educational message was straightforward and strong at the same time. A skill-based approach urged the social work community to develop knowledge as a way to think and act inside and outside the services. Trained social workers, the rest of the students, teaching professionals, and academics were all invited to use their knowledge in an integrated fashion when taking a decision, solving a problem, coping with a task, performing an analysis, defining a local project, and drafting a dissertation. Lecturers prompted students to exchange ideas by engaging them in active forms of teaching, based both on the research materials and the interaction and co-operation among students. For instance, students were invited to design their personal study environment in which, besides using a definite list of books, they could organise materials and training activities both in the classroom and "at home," in groups and individually. Moreover, the introduction of integrated educational modules provided lecturers with a teaching aid, even though it required a certain effort on their part, and helped students prepare for their tests, which were reduced in number. Three solutions were found to enhance didactic integration and an interdisciplinary approach. Firstly, exams provided for interactive activities, with more textbooks and materials covered in a single test. Secondly, teaching resources (lectures, textbooks, handouts, seminars, and lecturers) that could be associated either with a course, single classes, or a module. For instance, the same textbook could be assigned for several subjects. Thirdly, the programme including workshops and traineeships. In addition to what has already been discussed in the previous section, at the beginning of each workshop, students' proficiency levels and learning needs were identified by means of procedures that made it possible to set goals and consequently find the suitable teaching materials. Activities were all based on teaching units (each class was dedicated to a specific topic), with students working in couples/groups and with non-lecture methods. 
Experience seems to show that it is possible to achieve convergence of theoretical juxtapositions and overcome them. They are by no means neglected but, conversely, tackled and made instrumental to a learning process based on mastering interaction modalities and common socio-cultural tools (Allal, 1999). The presence of students with different educational backgrounds was not a barrier to learning. On the contrary, it enriched their education. Interdisciplinary skills and professional identity were intertwined, mainly through the participation and acknowledgement of the professional community. To sum up, 10 years' experience in coordinating the educational programme of the Master's degree in social work revealed a number of "mechanisms" that facilitated and characterised the educational offering addressed to social workers and other practitioners:

1. The unceasing opportunity to exchange ideas. Have a dialogue and discussions among lecturers and a direct communication channel with the Dean of the course, who regularly requested adjustments and changes, which were adopted in a participated and shared fashion;

2. The pressure to change the modes of university education, brought about by ministerial reforms and the will to define a way in the context of the city of Rome;

3. The need to meet the educational demand of practitioners, by engaging them in the new requests made by the students who were not social workers;

4. Frequent exchanges among academics, professionals, and the consultants and experts not belonging to academia or the profession, who offered their contribution to the analysis of contemporary social work, through seminars, research groups, open discussions, reports, papers, and public communications;

5. The will to continue (or engage in) research activities, by favouring specific training on issues of assessment and changes in the welfare systems and social services;

6. The collegial work within the group of lecturers and supervisors, as well as the appointment of a social worker acting as a tutor overseeing traineeships, with the support of the university traineeship co-ordinator (this was seen as an exclusive and privileged "space" for reflection on the profession, with the traineeships being assessed by supervisors and co-ordinators jointly).

\section{Final Considerations}

There are no other elements to assess this experience. However, considering the number of students who completed their studies in the allocated time, this integrated teaching approach seems to provide considerable advantages. The mechanisms listed above (but there may be others too) produced three effects in many students and certainly in most teachers. Firstly, there was a "learning effect," when the teaching programme (for instance, the integrated modules of several exams) led to new contents being introduced, sometimes through cooperation among lecturers (or students), or when students learned new professional tasks, even by readjusting prior knowledge. Secondly, there could be a "contrast effect," or a search for new learning and/or training methods, oriented towards a team, rather than a personal approach in defining contents and distributing tasks, or a generic redefinition of one's role and tasks. Thirdly, a "revaluation effect" was also identified, which translated into the ability to reconnect theoretical approaches and didactic contents with social work and policies. These led to a new educational method and style in social practice with its own operating modes (integrated modules, interdisciplinary workshops, shared programmes, interdisciplinary exams, and dissertations). The cultural and cognitive dimensions of professional social work issues were therefore enhanced. Students could experience their own roles as social workers, discuss the terms of their jobs, network 
with other colleagues (students and/or operators who were not social workers), co-operate, review modes of action, and meet operators with different backgrounds (sociologists, psychologists, researchers, etc.).

The integration between sociological theory and professional practice in the traineeships of the Master's degree programme of Sapienza University can also be construed in Bourdieu's terms (2005), as a set of "principles that generate and organise practices and representations that may be objectively suitable for their purpose without presupposing the conscious setting of goals and the explicit ownership of the operations necessary to achieve them, which are objectively 'regulated' and 'regular' without being produced through compliance with the rules.” The traineeship programme was presented to students as work that, in a real, practical, and relevant circumstance, helped them define the "habitus" of the social worker who translated sociological theory into practice and liaised with other professionals, and enabled professional identity to take shape in the service.

All in all, the educational experience of social policy specialists could be compared (and not juxtaposed) with that of social workers only by using the common ground of a type of social work that enhances different sources of knowledge, theory building through practice, and the formalisation of in-field experiences. The analysis of the Master's degree programme has identified those teaching conditions which somehow enabled integrated learning and the offering of different educational pathways, albeit in the single context (social work), which, as Fargion (2009) wrote, "takes the form of a wealth of stimuli and of a 'disorderly' setting that is open to several, even contradictory, interpretations and in which the outcomes of actions are never fully predictable.” The main sense not only of academia but also of professional social work seems to be the provision of educational opportunities in which the analytical reflection develops thoughtful and critical professionalism.

\section{References}

Allal, L. (1999). Acquisition et évaluation des compétences en situation scolaire (Acquisition and assessment of skills in school situations). In J. Dolz, \& E. Ollagnier (Eds.), L' énigme de la compétence en éducation (The Enigma of Competence in Education). Bruxelles: De Boeck.

Bourdieu, P. (2005). Il senso pratico (The practical sense). Roma: Armando.

Fabre, M. (1999). Epistemologia della formazione (Epistemology of education). Bologna: CLUEB.

Fargion, S. (2009). Il servizio sociale—Storia temi dibattiti (Social service—History, issues, and debates). Bari: Editori Laterza.

Reboul, O. (1996). Introduzione alla retorica (Introduction to rhetoric). Bologna: Il Mulino.

Wenger, E. (1998). Communities of practice: Learning, meaning, and identity. New York: Cambridge University Press. 


\title{
The Views of University Students on Guilt in Turkey
}

\author{
Sevda Aslan \\ University of Kırıkkale, Kırıkkale, Turkey
}

\begin{abstract}
In this study, it is aimed to determine the views of university students on guilt. The study group consisted of 272 students at all levels studying at Ondokuz Mayıs University Faculty of Arts and Sciences, Dokuz Eylul University Faculty of Arts and Sciences, Ahi Evran University Faculty of Arts and Sciences, Karabuk University Faculty of Engineering, and Nigde University Faculty of Economics and Administrative Sciences in Spring semester 2015. There were 155 female students and 117 male students participating in the study. In order to determine the views of university students, guilt form "University Students' Views on Guilt" was developed by the researcher. Each form consisted of 10 open-ended questions related to the students' views about guilt. The answers given to the 10 open-ended questions were combined and gathered under common headers. This is a descriptive study. The results of this study find that the opinions of university students on guilt include criminal actions in learned, especially from family, friends, and so on, and aggressive thoughts due to family insufficient, the characteristics nurtured by which can be easily hurt.
\end{abstract}

Keywords: university students, guilt, student views

\section{Introduction}

Infants are not good or bad. They are simply beings that are in interaction with their environment and undergoing constant growth. It is their experiences that make them good or bad. Crime, on the one hand, refers to the act that takes place in the public sphere and violates certain rules or laws, and as a result, is met with legitimate punishment and the intervention of the public authorities. Crime, on the other hand, is a social problem (Öztürk Çopur, Ulutaşdemir, \& Balsak, 2015). Criminality results from a conflict that pits the individual against other members of the society. Factors that lead adolescents to crime can be divided into two main categories: Individual factors and environmental factors. Individual factors explain only a small proportion of the crimes committed by adolescents. The major environmental factors that lead adolescents to crime are family, school, workplace, city, and peers (Gültekin Akduman, Akduman, \& Cantürk, 2007). Guilt is the result of the interaction between the individual and her/his environment. To eliminate feelings of guilt, its causes should first be removed (Küçük \& Acet, 2002). Moreover, it is known that, during adolescence period, some personality structures are challenged more compared with the other periods, which gives rise to the disintegration of personality structures that is difficult to recover. The cases of committing crimes or suicide, and the bouts of mental illnesses are often observed during this period, and they are considered as unhealthy ways to cope with internal and external strains caused by unhealthy and insecure personality structures (Kıliçc1, 2000).

Sevda Aslan, Dr., associate professor, Department of Educational Sciences Psychological Counselling and Guidance, University of Kırıkkale. 


\section{Literature Review}

In a review of studies conducted on guilt, Köksal and Gençdoğan (2007) found that there were no significant differences between university students with and without depression in terms of feelings of guilt and shame. The authors found that concepts of guilt and shame were related. They also found that girls experienced feelings of guilt and shame more frequently than boys. In a survey of university students, Erden and Akbaş (2015) found that an increased sense of guilt was associated with higher levels of compatability and responsibility. They found that the personality trait of compatability was a positive predictor of feelings of guilt for both sexes, but the personality trait of responsibility was a predictor of feelings of guilt only among men. Emir Öksüz and Bilge (2014) found that levels of feelings of guilt and shame among university students were not significant predictors of suicidal tendencies. Sankır (2014) found that high self-esteem among 11th grade high school students inhibited deviant and criminal behavior, whereas low self-esteem accelerated and facilitated engaging in deviant or criminal behavior. Aslan (2015) found that the most positive perception of the relationship between parents and high school students who are crime-prone and pushed to commit crimes is that families trust these students in their drive to make the most suitable decision, develop the most appropriate concept and the most proper behaviour about themselves among other choices, and therefore select the most appropriate motive. The other perception is that, when families are concerned about their academic success and when these students are far away from home, families believe these students make the appropriate move.

From another perspective, Karasu (2008) found that more crimes are committed in highly urbanized and economically developed cities that have a high share of the GDP (Gross Domestic Product), and high population densities and net migration. Ayar and Öztürk (2015) found that master's theses in Turkey identified urbanization and socio-economic factors as the causes of juvenile delinquency, and Ph.D. dissertations identified social circumstances, cases of child abuse, and school-related factors amongst the causes. Sığrı, Tabak, and Sağır (2010) found that the dominant feeling among women was shame, whereas the dominant feeling among men was guilt. Özen and Sümer (2013), in their study on married couples, identified three dimensions of expressing guilt: apology/compromise, denial, and explanation. In conclusion, crime is one of the biggest obstacles to social development. In this light, this study aims to identify the opinions of university students on guilt.

\section{Method}

The studies aiming to define a situation, which already exists or existed in the past, are studies designed according to scanning model (Karasar, 2003). In this study, an existing situation was analysed since the study aimed to determine the views of university students on guilt. Therefore, this study is a patterned research designed according to scanning model.

\section{Participants}

In this study, it is aimed to determine the views of university students on guilt. The study group consisted of 272 students at all levels studying at Ondokuz May1s University Faculty of Arts and Sciences, Dokuz Eylul University Faculty of Arts and Sciences, Ahi Evran University Faculty of Arts and Sciences, Karabuk University Faculty of Engineering, and Nigde University Faculty of Economics and Administrative Sciences in Spring semester 2015. The number of female students participating in the study was $155(56.99 \%)$ and the number of male students participating in the study was 117 (43.01\%). 


\section{Research Insturment}

The guilt form "University Students' Views on Guilt" was developed in order to determine the views of university students on guilt. Each form consisted of 10 open-ended questions to determine their views about guilt.

\section{The Analysis of the Data}

The answers given to the 10 open-ended questions in the form were combined and gathered under common headers. Frequencies and percentages were calculated.

\section{Results}

\section{Results on University Students' Perception of Guilt}

In this section, you can see the frequency $(n)$ and percentage (\%) distributions according to the answers given to the items in the "University Students' Views on Guilt."

Table 1

Distribution of Frequencies (n) and Percentages (\%) of Student Opinions on the Characteristics to Facilitate the Emergence of Guilt Behavior Features

\begin{tabular}{lll}
\hline Opinions & Frequency $(n)$ & Percentage (\%) \\
\hline Social class conflict & 70 & 25.74 \\
High unemployment rate & 64 & 23.53 \\
Migration from the village to the city & 55 & 20.22 \\
Poverty & 48 & 17.65 \\
Belong to subcultures & 35 & 12.86 \\
\hline
\end{tabular}

As seen in Table 1, 25.74\% of the students mentioned "social class conflict" as the most important personal chracateristics, whereas $12.86 \%$ of the students mentioned "belong to subcultures" as the least important characteristics.

Table 2

Distribution of Frequencies (n) and Percentages (\%) of Student Opinions on the Characteristics to Complicate the Processing of Crime

\begin{tabular}{lll}
\hline Opinions & Frequency $(n)$ & Percentage (\%) \\
\hline Security cameras & 104 & 38.24 \\
Preventive patrol services & 77 & 28.31 \\
Private security staff and systems & 63 & 23.16 \\
Physical environment regulations & 28 & 10.29 \\
\hline
\end{tabular}

As seen in Table 2, 38.24\% of the students mentioned "security cameras" as the most important personal chracateristics, whereas $10.29 \%$ of the students mentioned "physical environment regulations" as the least important characteristics.

As seen in Table 3, 59.19\% of the students mentioned "criminal actions in learned, especially from family, friends, and so on" as the most important personal chracateristics, whereas $40.81 \%$ of the students mentioned "criminal behavior learned in relationships with other individuals in the interaction process" as the least important characteristics. 
Table 3

Distribution of Frequencies (n) and Percentages (\%) of Student Opinions on the Process to an Individual's Criminal Behavior

\begin{tabular}{lcc}
\hline Opinions & Frequency $(n)$ & Percentage $(\%)$ \\
\hline Criminal actions in learned, especially from family, friends, and so on. & 161 & 59.19 \\
Criminal behavior learned in relationships with other individuals in the interaction process. & 111 & 40.81 \\
\hline
\end{tabular}

Table 4

Distribution of Frequencies (n) and Percentages (\%) of Student Opinions on Self-Harm Behavior Showing Youths of Family Features

\begin{tabular}{lll}
\hline Opinions & Frequency $(n)$ & Percentage $(\%)$ \\
\hline Family insufficient, the characteristics nurtured by which can be easily hurt. & 136 & 50 \\
Having conflicted marital relationships. & 136 & 50 \\
\hline
\end{tabular}

As seen in Table 4, 50\% of the students mentioned "family insufficient, the characteristics of which can be easily hurt" as the most important personal chracateristics, whereas $50 \%$ of the students mentioned "having conflicted marital relationships" as the least important characteristics.

Table 5

Distribution of Frequencies (n) and Percentages (\%) of Student Opinions on Overcoming Feelings of Guilt

\begin{tabular}{lll}
\hline Opinions & Frequency $(n)$ & Percentage $(\%)$ \\
\hline Build positive relationships with others. & 98 & 36.03 \\
To understand the feelings of empathy towards making. & 88 & 32.35 \\
Strives to eliminate the negative status. & 86 & 31.62 \\
\hline
\end{tabular}

As seen in Table 5,36.03\% of the students mentioned "build positive relationships with others" as the most important personal chracateristics, whereas $31.62 \%$ of the students mentioned "strives to eliminate the negative status" as the least important characteristics.

Table 6

Distribution of Frequencies (n) and Percentages (\%) of Student Opinions on Relation Between Education Level and Crime Behavior

\begin{tabular}{lll}
\hline Opinions & Frequency $(n)$ & Percentage $(\%)$ \\
\hline Train to influence the behavior of individuals and relationships. & 92 & 33.82 \\
Create humane and rational solution to the problems of education. & 90 & 33.09 \\
To create awareness in people's education. & 90 & 33.09 \\
\hline
\end{tabular}

As seen in Table 6, 33.82\% of the students mentioned "train to influence the behavior of individuals and relationships" as the most important personal chracateristics, whereas $33.09 \%$ of the students mentioned "to create awareness in people's education" as the least important characteristics.

As seen in Table 7, 34.93\% of the students mentioned "the low education level of the parents" as the most important personal chracateristics, whereas $17.28 \%$ of the students mentioned "divorce of parents" as the least important characteristics.

As seen in Table 8, 37.87\% of the students mentioned "to eliminate the factors driving the trends in the crime of child" as the most important personal chracateristics, whereas $6.98 \%$ of the students mentioned "criminals and modify child support" as the least important characteristics. 
Table 7

Distribution of Frequencies (n) and Percentages (\%) of Student Opinions on the Reason to the Criminal Behavior of Individuals

\begin{tabular}{lll}
\hline Opinions & Frequency $(n)$ & Percentage $(\%)$ \\
\hline The low education level of the parents & 95 & 34.93 \\
Poverty & 66 & 24.26 \\
Parental unemployment & 64 & 23.53 \\
Divorce of parents & 47 & 17.28 \\
\hline
\end{tabular}

Table 8

Distribution of Frequencies (n) and Percentages (\%) of Student Opinions on Criminals Children's Reintegration

\begin{tabular}{lcc}
\hline Opinions & Frequency $(n)$ & Percentage $(\%)$ \\
\hline To eliminate the factors driving the trends in the crime of child & 103 & 37.87 \\
To help society adapt to changing conditions & 81 & 29.78 \\
To guarantee the rights of the child & 69 & 25.37 \\
Criminals and modify child support & 19 & 6.98 \\
\hline
\end{tabular}

Table 9

Distribution of Frequencies (n) and Percentages(\%) of Student Opinions on Parental Attitudes in the Emergence of Guilt Feelings in Children

\begin{tabular}{lll}
\hline Opinions & Frequency $(n)$ & Percentage $(\%)$ \\
\hline Repressive attitude of parents & 100 & 36.76 \\
The punitive attitude of parents & 68 & 25 \\
The admonishment attitude of parents & 67 & 24.63 \\
Extremely intimidating attitude of the parents & 37 & 13.61 \\
\hline
\end{tabular}

As seen in Table 9, 36.76\% of the students mentioned "repressive attitude of parents" as the most important personal chracateristics, whereas $13.61 \%$ of the students mentioned "extremely intimidating attitude of the parents" as the least important characteristics.

Table 10

Distribution of Frequencies (n) and Percentages (\%) of Student Opinions on Causes of Juvenile Delinquency

\begin{tabular}{lll}
\hline Opinions & Frequency $(n)$ & Percentage $(\%)$ \\
\hline Aggressive thoughts & 141 & 51.84 \\
Emotional arousal & 131 & 48.16 \\
\hline
\end{tabular}

As seen in Table 10, 51.84\% of the students mentioned "aggressive thoughts" as the most important personal chracateristics, whereas $48.16 \%$ of the students mentioned "emotional arousal" as the least important characteristics.

\section{Discussion}

Reasons for resorting to guilt as listed according to the opinions of university students are as follows, according to priority: criminal actions in learned, especially from family, friends, and so on (161); aggressive thoughts (141); family insufficient, the characteristics nurtured by which can be easily hurt (136); security cameras (104); to eliminate the factors driving the trends in the crime of child (103); repressive attitude of parents (100); build positive relationships with others (98); the low education level of the parents (95); train to 
influence the behavior of individuals and relationships (92); and social class conflict (70). In the development and socialization of the individual, factors, such as structural characteristics of the family in which they were born and raised, whether the family performs its functions, and intra-family conflict, can all play a role in leading individuals to crime. The socioeconomic conditions of the family, social environment, and individual, genetic, and psychological factors also have an indirect effect on crime. A review of the literature shows that many children who commit crimes coming from broken homes, due to reasons, such as death, divorce or abandonment, having many siblings_-with an average number of five children in the family, or were separated from their families while growing up. Children who commit crimes usually have other people in their families or in their immediate social environment who were involved in crime. One of the most important factors leading children to commit crimes is being the victim of intra-family violence, negligence, or abuse. It is also argued that children with parents who have low levels of education are more at risk of getting involved in crime. Poor communication among parents or between parents and children is also a factor leading children to commit crimes (Acar, Demir, Görmez, \& Keser, 2015). The findings of this study are parallel with those of Acar et al. (2015) and Gültekin Akduman, Akduman, and Cantürk (2007).

\section{Conclusion and Recommendation}

In conclusion, family plays an important role in preventing criminal behavior in childhood. Aggression in family and among friends may encourage crime. Positive relationships should be established to prevent criminal tendencies, parents should be better educated to eliminate abusive behavior, and steps should be taken to avoid conflict between the individual and the society, improve children's social integration, and help social development. In light of these findings, the following recommendations are made: Families should be provided crime prevention guidance that fits their biological, psychological, and social characteristics. In addition, efforts should be made to raise awareness among children concerning the concept of crime.

\section{References}

Acar, G., Demir, A., Görmez, D., \& Keser, I. (2015). Aile ve çocuk suçluluğu ilişkisi (Family and juvenile delinquency relationship). Hacettepe Üniversitesi Sağlık Bilimleri Fakültesi (Hacettepe University Faculty of Health Sciences Journal), 1(12), 651-656.

Aslan, S. (2015). Suça eğilimi olan lise öğrencilerinin ailelerine ilişkin algıları (The perceptions of tendency to crime's high school students regarding their family). Erzincan Üniversitesi Eğitim Fakültesi Dergisi (Erzincan University Journal of the Faculty of Education), 17(1), 282-294.

Ayar, D., \& Öztürk, C. (2015). Türkiye'de lisansüstü çalışmalarda çocuk suçluluğu (Juvenile delinquency in post graduate studies in Turkey). The Journal of Pediatric Research, 2, 17-20.

Emir Öksüz, E., \& Bilge, F. (2014). Üniversite öğrencilerinin intihar olasılıklarının incelenmesi (Examining the suicide probabaility among university students). Eğitim ve Bilim (Education and Science), 39(171), 407-420.

Erden, S., \& Akbağ, M. (2015). How do personality traits effect shame and guilt? An evaluation of the Turkish culture. Eurasian Journal of Educational Research, 58, 113-132. Retrieved May 5, 2015, from http://dx.doi.org/10.14689/ejer.2015.58.4

Gültekin Akduman, G., Akduman, B., \& Cantürk, G. (2007). Ergen suçluluğunda bazı kişisel ve ailesel özelliklerin incelenmesi (Investigation of the some personal and familial characteristics of juvenile deliquency). Türk Pediatri Arşivi (Turkish Archives of Pediatrics), 42, 156-161.

Karasar, N. (2003). Bilimsel araştırma yöntemi-kavramlar, ilkeler, teknikler (12. Bask1.) (Scientific research method-concepts, principles, technique [12th ed.]). Ankara: Nobel.

Karasu, M. A. (2008). Türkiye'de kentleşme dinamiklerinin suça etkisi (The effect of Turkey's urbanization dynamics on crime). Ankara Üniversitesi Hukuk Fakültesi Dergisi (Ankara University Journal of Law Faculty), 57(4), 255-281.

Kılıçc1, Y. (2000). Okulda ruh sağlı̆̆ (Mental health in school). Ankara: Anı Yayıncılık. 
Köksal, F., \& Gençdoğan, B. (2007). Depresif olanlar ile olmayanların suçluluk, utanç ve öfke tarzlarının incelenmesi (Depressive and non-depressive ones, examining their guilt, shame, and anger). Atatürk Üniversitesi Sosyal Bilimler Enstitüsü Dergisi (Journal of Graduate School of Social Sciences), 9(1), 163-175.

Küçük, V., \& Acet, M. (2002). Bir kişilik özelliği olarak suçluluk ve sporla ilişkisi (Guilt and sports relations as a personality trait). Dumlupınar Üniversitesi Sosyal Bilimler Dergisi (Dumlupınar University Social Science Journal), 7, 369-375.

Özen, A., \& Sümer, N. (2013). Evlilikte kızgınlık, üzüntü ve suçluluk duygularının ifade biçimlerinin ölçümü (Marriage anger, sadness, and measuring the expression of guilt). Türk Psikoloji Yazılarl (Turkish Psychological Articles), 16(31), 36-55.

Öztürk Çopur, E., Ulutaşdemir, N., \& Balsak, H. (2015). Çocuk ve suç (Child and guilt). Hacettepe Üniversitesi Sağlık Bilimleri Fakültesi (Hacettepe University Faculty of Health Sciences Journal), 1(2), 120-124.

Sankır, H. (2014). Gençlerin sapmış ve suçlu davranışlara yönelmelerinde benlik saygısının etkisi: Lise 11.sınıf örneği (Influence of self esteem on youths who tend to involve deliquent and deviant behaviors: Case study among 11th grade students). Turkish Studies International Periodical for the Languages, Literature and History of Turkish or Turkic, 9(2), 1311-1333.

Sığrı, Ü., Tabak, A., \& Sağır, A. (2010). Çalışanlarda suçluluk ve utanç duygusunun cinsiyet-yaş durumuna göre mukayesesi ve örgütlerde utanç yönetiminin kullanılması (A comparison of guilt and shame emotions of workers in terms of gender-age differences and "shame managment" in organizations). Cumhuriyet Üniversitesi İktisadi ve İdari Bilimler Dergisi (Cumhuriyet University Journal of Economics and Administrative Sciences), 11(1), 71-85. 


\section{Call for Papers or Books}

US-China Education Review A (Education Practice) (ISSN: 2161-623X) and US-China Education Review B (Education Theory) (ISSN: 2161-6248), the earlier title: US-China Education Review (ISSN: 1548-6613) are professional journals published across the United States by David Publishing Company, USA. These journals are regularly published by China National Publication Import \& Export Corporation on commission. If you have the idea of making our journal a vehicle for your research interests, please send electronic version of your paper to us.

US-China Education Review A \& US-China Education Review B are collected and indexed by the Library of U.S. Congress, on whose official Website (http://catalog.loc.gov) an on-line inquiry can be triggered with its publication number ISSN No. as key words in "Basic Search" column. In addition, these journals are also retrieved by some renowned databases:

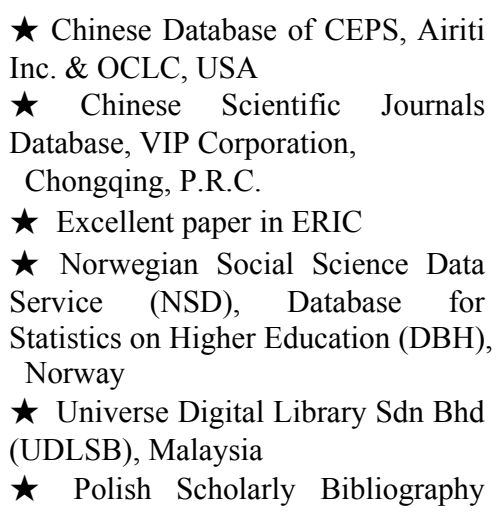

$(\mathrm{PBN})$
$\star$ Google Scholar
$\star$ CNKI
$\star$ J-GATE
$\star$ Scribd Digital Library
$\star$ Airiti
$\star$ Academic Key
$\star$ Electronic Journals Library
$\star$ CiteFactor
$\star$ SJournal Index
$\star$ Scientific Indexing Services
$\star$ New Jour

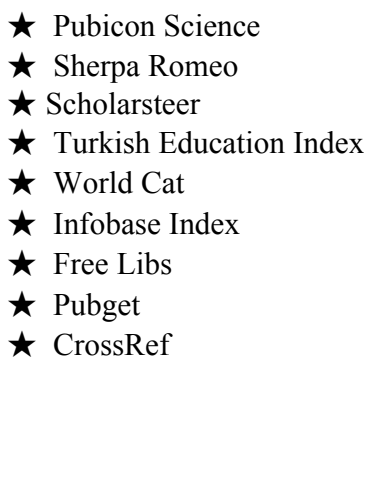

Current columns involve Higher Education, Higher Educational Management, Educational Psychology, Teacher Education, Curriculum and Teaching, Educational Technology, Educational Economics and Management, Educational Theory and Principle, Educational Policy and Administration, Sociology of Education, Educational Methodology, Comparative Education, Vocational and Technical Education, Special Education, Educational Philosophy, Elementary Education, Science Education, Lifelong Learning, Adult Education, Distance Education, Preschool Education, Primary Education, Secondary Education, Art Education, Rural Education, Environmental Education, Health Education, History of Education, Education and Culture, Education Law, Educational Evaluation and Assessment, Physical Education, Educational Consulting, Educational Training, Moral Education, Family Education, as well as other issues.

David Publishing Company is strived to provide the best platform for researchers and scholars worldwide to exchange their latest findings and results. We admire your achievements, and we understand how important your research impact on other peers in the same interest field and other disciplines, and how delighted you would be when communicating with global professional peers. Your contribution to our journals would be very much welcome!

\section{Requirements:}

(1) Paper must be empirical or theoretical contributions without being published previously;

(2) All other scholars' words or remarks as well as their origins must be indicated if quoted;

(3) English title, abstract and key words should be prerequisite;

(4) Patterns or forms should conform to the standard listed in our Website;

(5) Automatic paper submission system is strongly recommended, while e-mail attachment can be sent through e-mail at teacher@davidpublishing.com; teacher@davidpublishing.org; education1548@hotmail.com; or edu1658@yahoo.com.

Please visit our Website at http://www.davidpublisher.com for our automatic paper submission systems.

Should you have any questions or concerns, please feel free to contact us.

Best regards,

US-China Education Review A \& US-China Education Review B

David Publishing Company 


\section{US-China Education Review B}

Volume 6, Number 10, October 2016

David Publishing Company

616 Corporate Way, Suite 2-4876, Valley Cottage, NY 10989, USA

Tel: 1-323-984-7526, 323-410-1082; Fax: 1-323-984-7374, 323-908-0457

http://www.davidpublisher.com, www.davidpublisher.org

teacher@davidpublishing.org, teacher@davidpublishing.com 